DOE/NASA CONTRACTOR REPORT

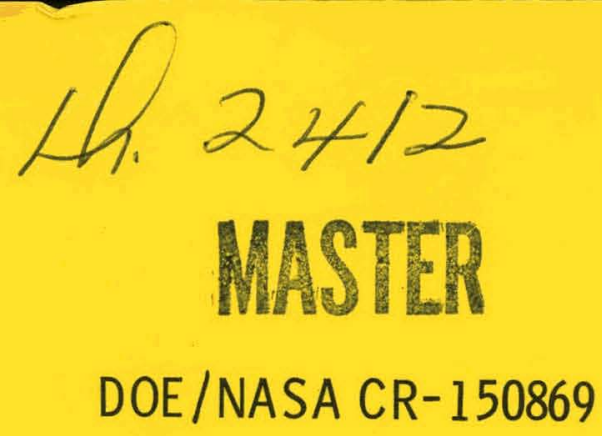

\title{
FINAL SYSTEM INSTRUMENTATION DESIGN PACKAGE FOR DECADE 80 SOLAR HOUSE
}

Prepared from documents furnished by

Copper Development Association, Inc.

405 Lexington Avenue

New York, New York 10017

Under Contract NAS8-32244 with

National Aeronautics and Space Administration

George C. Marshall Space Flight Center, Alabama 35812

For the U. S. Department of Energy

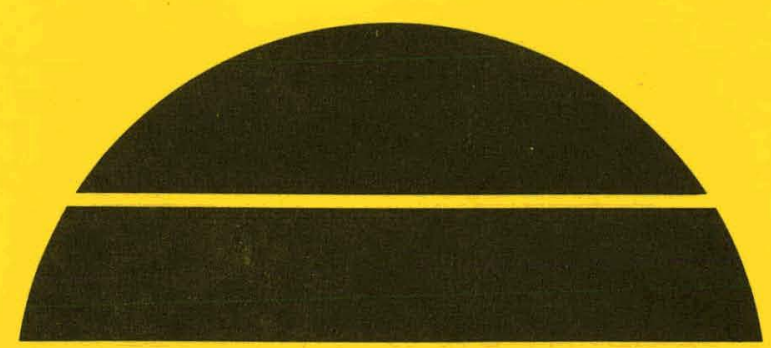

\section{U.S. Department of Energy}




\section{DISCLAIMER}

This report was prepared as an account of work sponsored by an agency of the United States Government. Neither the United States Government nor any agency Thereof, nor any of their employees, makes any warranty, express or implied, or assumes any legal liability or responsibility for the accuracy, completeness, or usefulness of any information, apparatus, product, or process disclosed, or represents that its use would not infringe privately owned rights. Reference herein to any specific commercial product, process, or service by trade name, trademark, manufacturer, or otherwise does not necessarily constitute or imply its endorsement, recommendation, or favoring by the United States Government or any agency thereof. The views and opinions of authors expressed herein do not necessarily state or reflect those of the United States Government or any agency thereof. 


\section{DISCLAIMER}

Portions of this document may be illegible in electronic image products. Images are produced from the best available original document. 
NOTICE

This report was prepared to document work sponsored by the Unfted States Government. Nelther the United States nor its agents the United States Departmant of Energy, the United States National Aeronaut1cs and Space Adminfatration, nor any federal employees, nor any of thef. contractors, sutcutractors or their employees, make any warranty, express or 1 miflited, or assume any legal liabllity or responsibllity for the sccuracy, completeness, or usefulness of any information, apparatus, product or process disclosed, or represent that its use would not infringe privately owned rights. 


\section{PAGES $\mathrm{i}$ to $\mathrm{ii}$ WERE INTENTIONALLY LEFT BLANK}


1. 0 Site and System Description 1

2.0 Operating and Control Modes 9

Figure 1 - View of Decade 80 Solar House Showing Collector Orientation and Pyranometer Location

Figure 2 - Floor Plan Showing Loration of Site Instrumentation Instrument Hardware

3.0 Instrumentation Program Draing IP 7933729 Rev H

Appendix B Drawings - Heat Transfer Fluid Flows for

Six Basic Opcrating Modes:

- Energy Collection

$\mathrm{B}-1$

- Heating from Storage

$B-2$

- Heating from Auxiliary

$\mathrm{B}-3$

- Cooling from Storage

$\mathrm{B}-4$

- Cooling from Auxiliary

B -5

- Domestic Water Heating

B-6

Appendix C Drawing, Heating and Cooling Water Piping Diagram

C -1 
THIS PAGE

WAS INTENTIONALLY

LEFT BLANK 


\section{SECTION 1.0}

\section{SITE AND SYSTEM DESCRIPTION}


1.0 Site and System Description

1.1 Site Contractor

Copper Development Association Inc.

405 Lexington Avenue

New York, New York 10017

(212) 953-7315

Field office:

34 E. Madrid Place

Tucson, Arizona 85704

$(602): 297-7020$

1.2 Site Address

.7779 N. Via Piccolina

Tucson, Arizona 85704

1.3 Purpose of site

Single family residence.

1.5 System Descriptive Summary

1.5.1. Type:

Heating, absorption air-conditioning, and domestic water heating.

1.5.2 Collector area:

Gross area $=1923 \mathrm{sq} \mathrm{ft}$

Clear aperture $=1766 \mathrm{sq} \mathrm{ft}$

1.5.3 Collector description:

The collector is the Revere Copper and Brass Inc. Laminated panel Collector, integral with the building roof. The collector is glazed with two panes of $1 / 8-$ inch glass preassembled in a frame. The glass is PPG.

Herculite $K$ tempered glass as the outer pane, and annealed glass as the inner pane. 
Flow through the collector is $25 \mathrm{gpm}$; mass flow

is about $6.5 \mathrm{lb} / \mathrm{sq} \mathrm{ft}-\mathrm{hr}$. Flow is through a gridsinuous pattern of 22 parallel tubes. Each tube is folded back-and-forth in a sinuous path of about $200 \mathrm{ft}$ with a balancing cock in each flow path. 
1.5.6 Hot water subsystem:

Domestic water is heated through a heat exchanger and stored in a 66-gallon electric water heater, Rheem model $666 \mathrm{H}-660$. The water heater electric elements are wired so they are in-circuit only when the main storage tank is below a preset temperature.

Hot water is circulated continuously to faucets throughout the house.

1.5.7. Energy transport:

$\underline{\text { Fans }-A l l}$ are $120 \mathrm{~V} \mathrm{AC}$, Single phase, $60 \mathrm{~Hz}$.

East zone uses one 3/4-HP blower.

West zone uses one 1/2-HP. blower.

There is a duct booster-fan that controls air flow to the guest cabana. The fan is operated by the homeowner when he desires.

Ducts - All ducts are rigid fiberglass, in diameters from 6" to 16". The duct layout is shown in Drawings, enclosed as Appendix A.

Air flow through the east system is $1750 \mathrm{cfm}$; air flow through the west duct system is $1500 \mathrm{cfm}$.

Pumps - All pumps are $120 \mathrm{~V}$ AC, single phase, $60 \mathrm{HZ}$. 
Water Piping Diagram (Appendix C) gives a detailed description of each pipe size and identifies all pumps, valves, heat exchangers, etc.

All tubes between the collector and $\mathrm{HE}-1$ and HE-2 are $1-1 / 2$ inch. All tubes into and out of the storage tank are 1-1/2 inch.

Tubes to and from the Arkla generators and condensers, and tubes to each heating fan coil, are 1 inch,

A 1 tubing is Type I copper. Fittings are copper, brass, or bronze. All joints are brazed with "Sil-Fos": silver-phosphorous-copper brazing alloys.

Fluid type - All fluids are tap water.

The collector water has about $35 \%$ propylene glycol antifreeze added to $1 t$. . It is inhibited with phosphate.

The storage tank water has sodium nitrite and sodium sulfite added to it as rust inhibitors. About 10 lbs of each were used. The sodium sulfite is periodically replenished. This water circulates through the heating fan coils and the Arkla generators.

The cooling tower water has a polyphosphate stabilizer metered into it at about 1 to $10 \mathrm{ppm}$. An algaecide is added to the water once a month. The algaecide is consumed in a few days. The cooling tower 
water is bled off whenever the air conditioners are operating; bleed rate is $10.5 \mathrm{gal}$ per $\mathrm{hr}$ for each of the two Arkla air-conditioners.

1.5.8 Space cooling method:

Air-conditioners are three-ton Arkla lithium bromide absorption units, model XWF-501. Two are used; each cools one zone, or about half the living space. They are direct expansion types.

1.5.9 Auxiliary energy source:

Auxiliary energy for the heating and cooling subsystems is provided by a natural-gas-fired boiler: Teledyne Laars model HK--250--CNOlA. The labelled input is $250,000 \mathrm{Btu}$ per hr; output is $200,000 \mathrm{Btu}$ per hr.

The boiler has been modified by the removal of its two-stage gas valve, and replacement of it by a modulating valve and a partial bypass. Maximum output is now expected to be about 150,000 Btu per hr, with minimum continuous output about 50,000 Btu per hr. Auxiliary energy for domestic water heating is provided by the two electric heating elements within the domestic water storage tank. Each element is 4500 watts, wired to operate one at a time. Auxiliary electric power is allowed to come on only when the main storage tank temperature arops below a preset temperature: 
1.5.10 Operational control sequence:

The operational control sequence is described in detail in section 2.0 Operating and Control Modes

\subsubsection{Energy conversion efficiency:}

\section{Collection efficiency - The collector efficiency} has been measured continuously for over a year. Typical summertime day-long efficiency, integrated over the total run-time of the collector (about 10:30 a.m. to $3: 30$ p.m.) is about 24 to 268 . Typically 650,000 to $850,000 \mathrm{Btu}$ are delivered to storage on a normal clear day.

Typical wintertime day-long efficiency, integrated similarly, is 30 to 408 . Up to $1,100,000$ Btu are collected on a clear December or January day. Recall also that the collector is sloped at 260 above the horizontal, to emphasize collection of heat during the summer.

\section{Storage losses - Heat delivered from storage to} the HVAC system has been measured. On a typical day the air conditioning system draws from storage about 200,000 Btu less than -was delivered to storage by the $20, \cdots 0$ collector.

About half the 200,000 Btu appears to have been used for domestic water heating. The other half is attributed to losses through the storage tank insulation, plumbing insulation, and to measurement error. Storage losses in the heating mode have not yet been analyzed. 
Domestic water heating losses - The domestic

water storage tank/heater is wired to its own watthour meter. Domestic water heating energy consumption can therefore be measured by forcing the heater to remain in the electric heating mode. (It is set to the same temperature, $135 \mathrm{~F}$, that the solar water heating system.)

Typically the domestic water heating system will consume about $25 \mathrm{kwh}$ per day, with two occupants 1iving in the house. Of this amount, about $8 \mathrm{Kwh}$ per day is dissipated because of the continuous-circulation feature of the plumbing system. In addition, the circulator pump itself consumes about 2 kwh per day. Additional insulation was added to the domestic water storage tank during the past summer. Before it was added energy consumption by the subsystem was about 6 to $10 \mathrm{kwh}$ per day higher.

These measurements of electric energy consumption by the domestic water subsystem do not, of course, account for any losses that occur in the domestic water heat exchanger, $\mathrm{HE}-3$ or its associated plumbing.

Arkla C.O.P.' - Air-conditioner Coefficient of Performance has been measured approximately. Under steady-state operating conditions the COP of the Arklas has been measured at about $0.8 \pm 0.1$. Day-long COP varied, of course, with the amount of cooling required throughout the day. During the summer it was about 0.8. Early and late in the cooling 
season it was: lower, about 0.3 to 0.6 . During the summer both air-conditioners ran continuously from early morning till late night, typically 16 to 20 hours per day. Early and late in the cooling season. the machines cycled rather frequently, lowering their effective coefficients of performance. 
SECTION 2.0

\section{OPERATING AND CONTROL MODES}


There are six basic operating modes in the Decade 80 Solar House energy system:

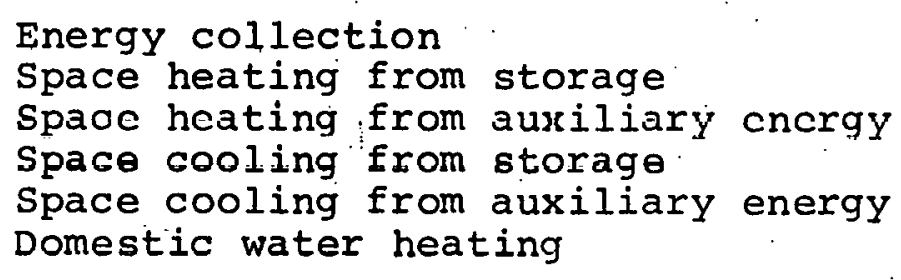

The heat transfer fluid flows for each of the six operating modes are shown schematically in the six drawings (Drawings 1 through 6 ) that make up Appendix $B$, and are described below.

2.1.... Energy collection:

Encrgy colleation is controlled by two differential thermostats (Rho sigma Model 12 modified units). When the collector surface temperature exceeds the temperature at the bottom of the storage tank pump P-1 is turned on, circulating the water-antifreeze solution from the collector to heat exchangers HE-1 and HE-2, and back to the collector.

A second differential thermostat turns pump P-2 on when the temperature of the antifreeze solution, as measured near the inlet of $\mathrm{HE}-1$, exceeds the temperature at the bottom of storage by about $3^{\circ} \mathrm{F}$. 
Pump P-2 circulates water from the bottom of the storage tank through $\mathrm{HE}-2$ and $\mathrm{HE}-1$, and back to the top of the storage tank.

All energy that is collected is delivered directly to the storage tank; there is no provision for bypass from the collector directly to the heating and cooling equipment.

2.2 Space heating from storage:

Upon demand for heat by either of the two room thermostats, pump P-3 draws water from the solar storage tank. Warm water is provided to both fan coils, but admitted only to the one for which a demand was registered. Heat can be provided to either or both heating zones.

Water flow to each fan coil is set at $6 \mathrm{gpm}$. Each fan coil has a water bypass, so that its status (on or off) does not effect the rate of water flow to the other fan coil.

2.3 Space heating from auxiliary energy Auxiliary heat, when required, is provided by a natural gas boiler. During the winter of 1975-1976 oniy $3 \%$ of the total heating Btu's were provided by the boiler. So far (January 1977) no auxiliary heat has been used during the current winter.

The heating system is controlled by a two-stage room thermostat in each zone. When the space temperature drops below the thermostat set-point, a stageone demand is created. Heat is provided to the space 
from the storage tank. "If the storage tank is too cold to satisfy the demand for heat, the space temperature will continue to drop.

When the space temperature drops $1.5 \mathrm{~F}$ helow the set-point of the thermostat a stage-two demand is created. If this demand continues for seven minutes the auxiliary boiler will operate. The boiler will continue to operate, and provide heat to both fan coils, until the stage-two demand for heat is satisfied.

It has been found that the boiler might be needed during the coldest part of a morning, but as the day begins to warm there is sufficient heat still in storage to satisfy the smaller demand. Therefore the auxiliary heat source is load-dependent rather than supply temperature-dependent.

The seven minute time delay on the boller was added to assure that the hoiler dnes not operate unnecessarily. The occupant of the house might over adjust a thermostat upward or open a door on a cold, windy morning. This might create a sudden false stage two demand for heat that could actually be satisfied by stored heat.

For economy, water heated by the boiler should not be returned to the storage tank after passing through the fan coil. Therefore, whenever the gas 
boiler operates, proportioning valve $\mathrm{V}-2$ moves to the full bypass position. In this position water travels from pump $\mathrm{P}-3$ to the boiler, then to the heating coils, and finally through $\mathrm{V}-2$ and back to the pump.

2. 4 Space cooling from storage:

When the occupant of the house chooses to cool the house he sets a Summer/winter switch to the Summer position. This causes valves $V-3$ and $V-4$ to deliver hot water to the Arklas instead of the fan coils.

For proper operation the Arkla air conditioners require hot water between 190 and $210 \mathrm{~F}$. The storage. tank may at times exceed $210 \mathrm{~F}$; therefore the stored hot water must be tempered somewhat. This is done by valve $\mathrm{V}-2$. If water from storage enters this valve too hot, cooler water returning from the airconditioners is mixed with the hot water, until the proper temperature is achieved.

The Arklas also require a means to dissipate the heat extracted from the house. This is the purpose of the cooling tower: The tower delivers water to the Arklas between 70 and $85 \mathrm{~F}$; the water is heated in the Arklas by 15 to 20 degrees and returned to the tower. At the tower some of the water is evaporated, causing the remaining water to be cooled. On a dry day the water may be cooled below $70 \mathrm{~F}$; this is not desirable. 
To maintain the cool water at no less than $70 \mathrm{~F}$ there is a proportioning valve, V-11, at the cooling tower. If the tower chills the water excessively, unchilled water is delivered to the bottom of the tower, instead of the top, from which it returns, unchilled, to the Arklas. Valve V-ll mixes chilled and unchilled water to achieve the proper temperature. Upon demand by either room thermostat for cooling,pumps $\mathrm{P}-3$ and $\mathrm{P}-6$ start, delivering hot water from storage and cool water from the cooling tower to the Arklas. Each Arkla has three-way valves and bypasses, so that cycling of one machine does not effect the water flow rates to the operating machine: The machines can operate alone or simultaneously.

As mentioned previously, the hot and cool water into the Arklas must be within certain temperature Iimits. If the cool water is too warm, or the hot water too cool, there is a danger of solidification, or crystallization, of the Iithium bromide solution. To prevent the possibility of solidification there is a safety thermostat on each Arkla. This thermostat is a differential type; it allows air-conditioner operation only when the hot water is at least $110 \mathrm{~F}$ hotter than the cool water. 2.5 Space cooling from auxiliary energy: The cooling system, like the heating system, is controlled by two two-stage thermostats, one in 
each of the two zones of the house. A first-stage demand for cooling from either thermostat will

operate its air-conditioner, if certain conditions are met. The first. condition, as described above, is that the hot water to the Arkla's generator must be at least $110 \mathrm{~F}$ hotter than the cool water to the machine's condenser. The second condition is that the hot water be at least $190 \mathrm{~F}$. If the water in the storage tank is below this temperature, thermostat $T-4$, in the storage tank, signals valve $\mathrm{V}-2$ to close to the recirculate position. This prevents the water in the storage tank from circulating uselessly and losing heat through pipe insulation.

A second stage demand from either room thermostat indicates that, that zone has warmed more than 1.5 degrees above the thermostat set-point. If the storage tank is above $197 \mathrm{~F}$, the second stage demand has no effect. If the tank is below $197 \mathrm{~F}$ a second stage demand will first cause valve $V-2$ to close to the recirculate position. It then causes proportioning valve $V-14$ to respond to its temperature sensor T-16. As $V-14$ begins to operate to admit water to the boiler, the opening of an end-switch on the valve allows the boiler circulating pump, $\mathrm{P}-10$, to start and sends a signal to the boiler gas valve. Flow through the boiler and P-lo trips a flow switch which then allows the boiler to begin operating. 
There is a modulating gas valve in the boiler. The valve's regulator is set to raise the incoming water temperature by about 10 to 12 degrees. The boiler also has an over-temperature thermostat, set to $230 \mathrm{~F}$, which shuts off the boiler if the water becomes too hot.

Modulating valve V-14 regulates the temperature of the water flowing from the boiler to the Arklas, holding the water to about $205 \mathrm{~F}$ :

The boiler will come on and operate both Arklas whenever there is a second-stage cooling demand from either thermostat. There is no time delay in the cooling mode, as there is in the heating mode.

If the storage tank temperature is between 190 and $197 \mathrm{~F}$, the Arklas will operate from solar storage upon first-stage cooling demands and from the auxiliary boiler when either thermostat ragisters a serond demand.

$2.6 \ldots$ Domestic water heating:

The final mode of operation is domestic water heating. Water is received from the city supply between 50 and $90 \mathrm{~F}$, and heated to 135. Domestic hot water is stored in a 66 -gallon commercial electric water heater, whose electric heating elements are normally disabled. 
The hot water is circulated continuously through the house past all faucets. The water temperature is sensed by thermostat $\mathrm{T}-7$ as the water returns to the base of the storage tank.

When the water temperature drops below $135 \mathrm{~F}$, T-7 causes pump $\mathrm{P}-4$ to start. This pump draws hot water from the solar storage tank and sends it through the shell side of $\mathrm{HE}-3$. After a 30-second delay (to allow the heat exchanger to warm up) pump $\mathrm{P}-5$ starts sending domestic water from its storage tank to the tube side of $\mathrm{HE}-3$. Both pumps run until T-7 is satisfied. During the summer, with the storage tank normally above $180 \mathrm{~F}$, these pumps run for a one to two minute cycle every hour or two. During the winter the pumps run somewhat longer and more frequently. Thermostat T-5 measures the storage tank temperature. If the main tank is below about $140 \mathrm{~F}$ pumps P-4 and $\mathrm{P}-5$ would run excessively, or continuously. Thus T-5 disables the pumps below its $140 \mathrm{~F}$ set-point, and instead puts the domestic water heater's electric heating elements into circuit.

3.0, Architectural Rendering

An aerial photograph of the Decade 80 solar House appears as Figure 1, page 18, showing pyranometer location and collector orientation. There are no interfering surrounding structures. 


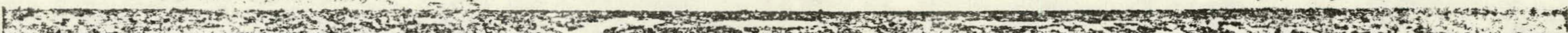

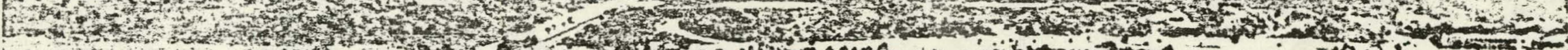

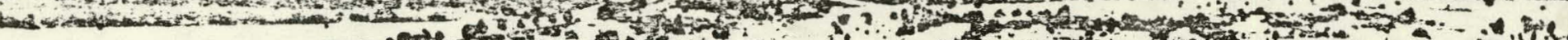

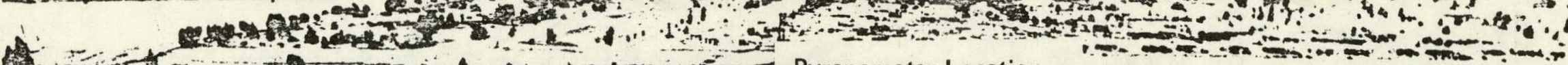

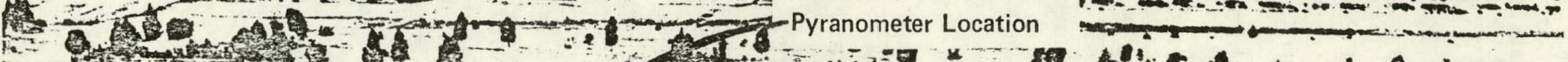

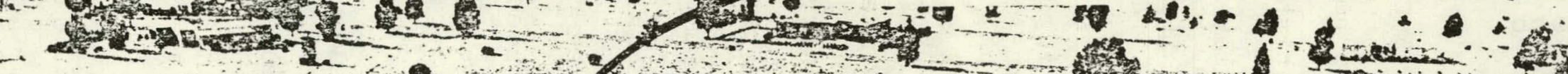

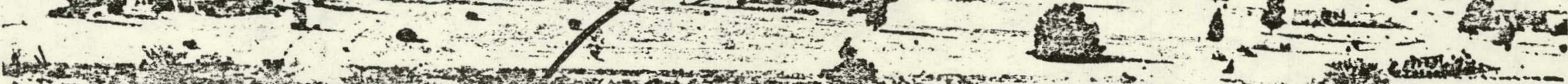

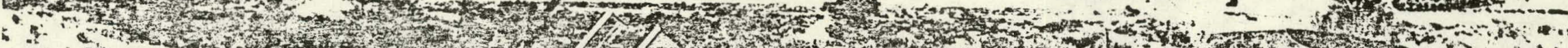

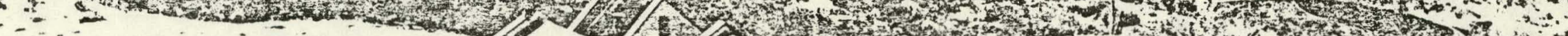

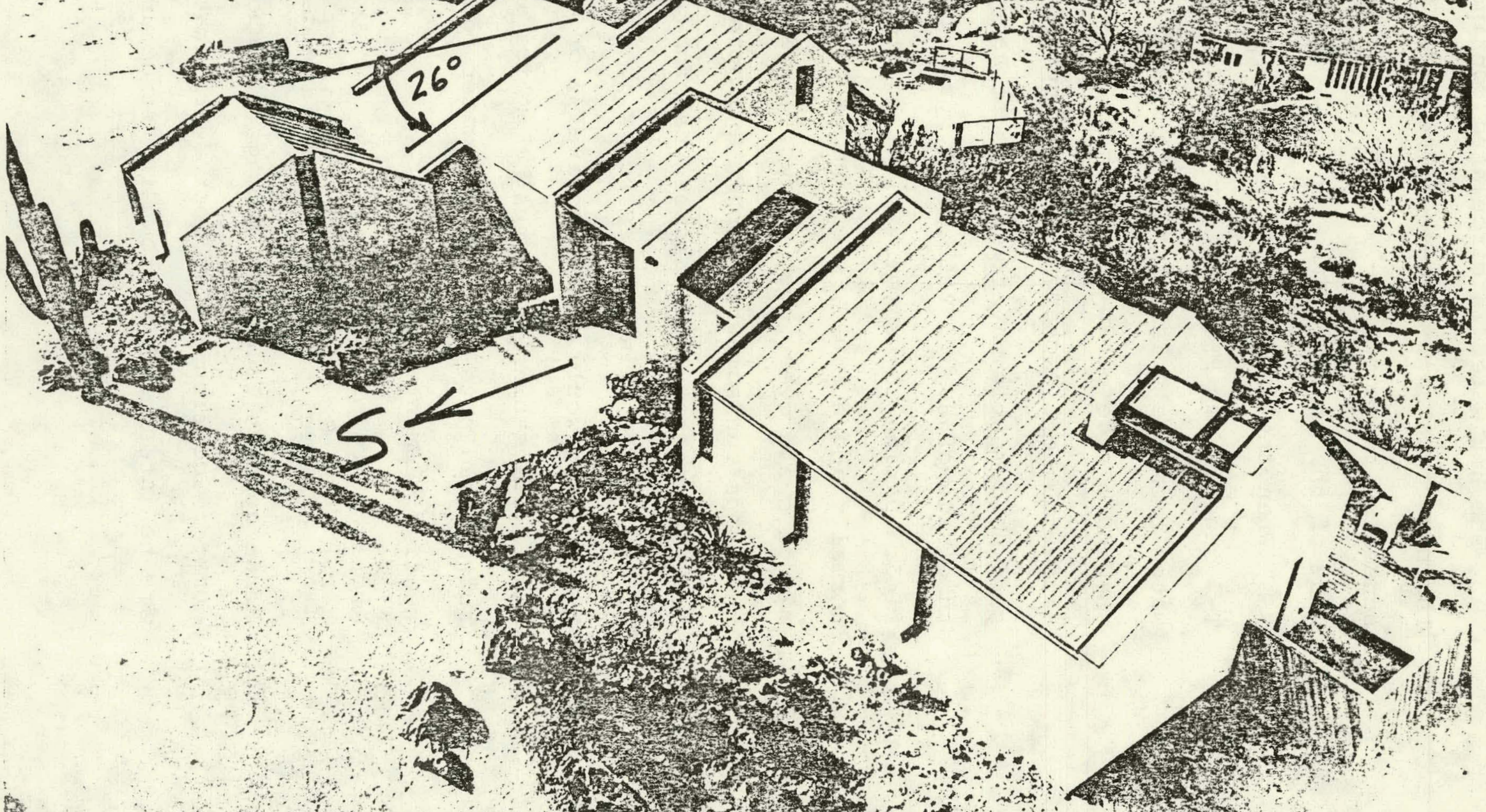

B.

FIGURE 1. VIEW OF DECADE 80 SOLAR HOUSE SHOWING COLLECTOR ORIENTATION AND PYRANOMETER LOCATION 


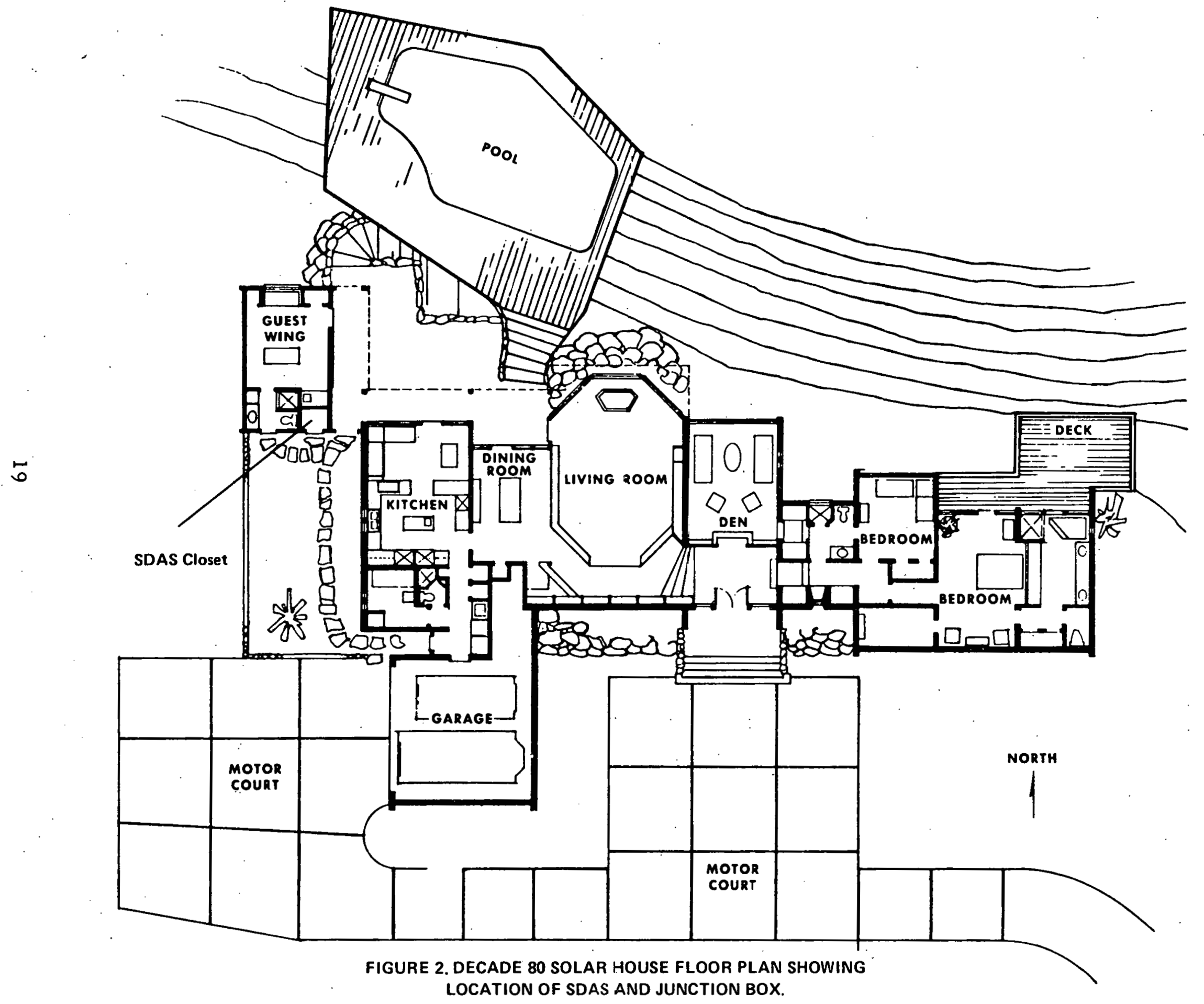


SECTION 3.0

INSTRUMENTATION PROGRAM 


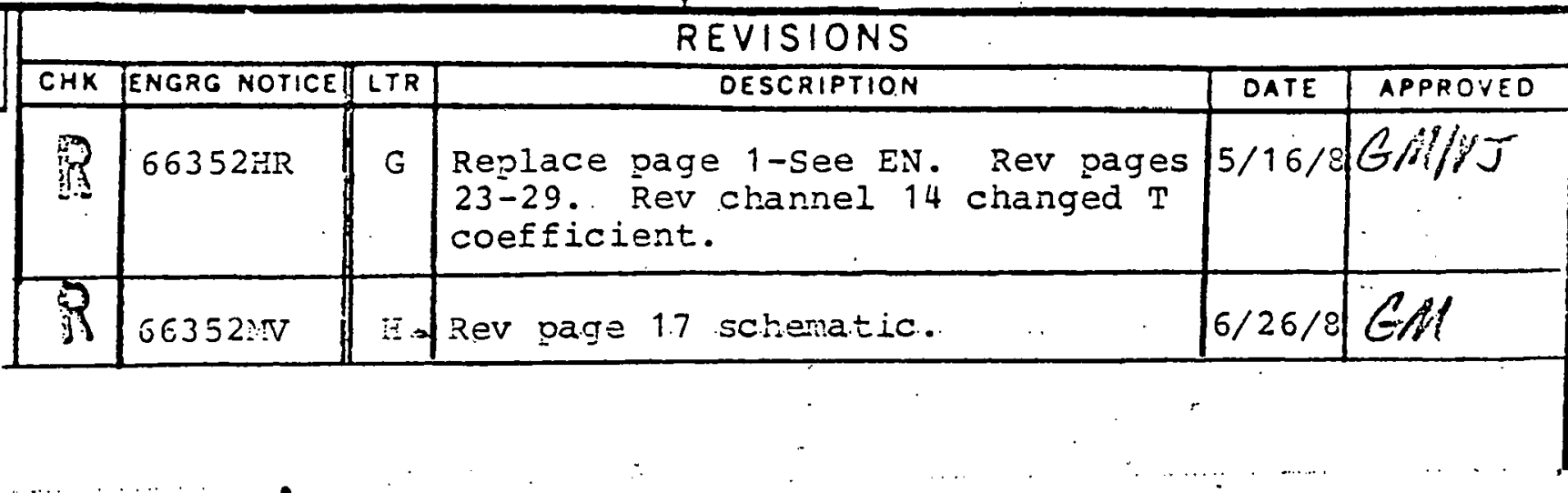

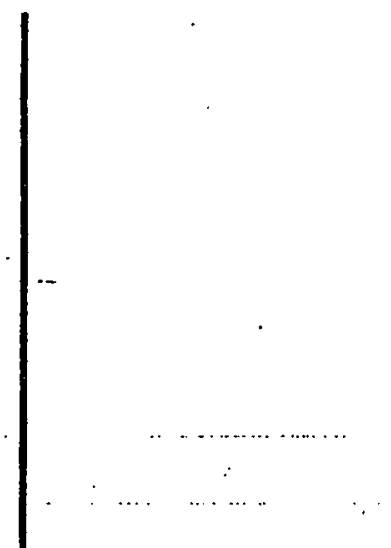

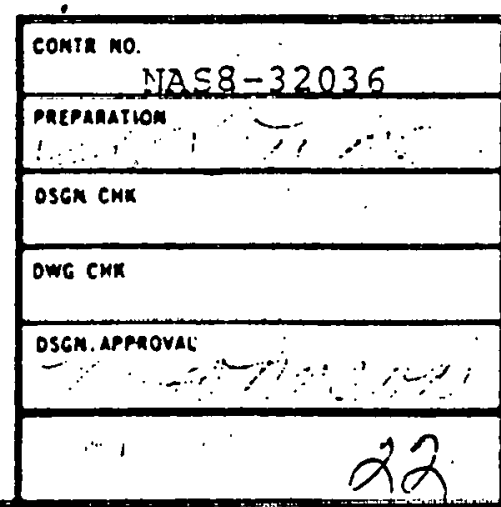

INTERNATIONAL BUSINESS MACHINES CORP. FEDERAL SYSTEMS DIVISION HUNTSVILLE, ALA, 35807

TITLE INSTRUMEINTATION PROGRAM

DECADE 80 IIOUSE

\begin{tabular}{|c|c} 
SIZE & CODE IOENT NO \\
20234
\end{tabular}

WT 


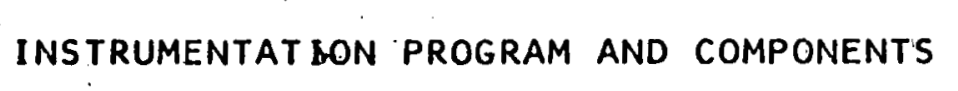

LIST -- $\frac{\text { DECADE } 80 \text { HCUSE }}{\text { IP } 7933729}$

$\frac{4 / 25 / 77}{\text { REV }}$

INTRODUCTION

THIS DOCUMENT DEFINES AND CONTROLS THE MEASURING REQUIREMENTS AND INSTRUMENTATION SYSTEM APPLICATIONS FOR A SOLAR HEATING AND COOLING OPERATIONAL SITE.

THE SECTIONS OF. THIS DOCUMENT ARE DESCRIBED AS FOLLOWS:

1. PREAMBLE SECTION - CONTAINS DESCRIPTIONS, EXPLANATIONS, INSTRUCTIONS AND DIAGRAMS NECESSARY TO UNDERSTAND. THIS DOCUMENT AND THE APPLICATION OF THE DATA COLLECTION SYSTEM TO A SPECIFIC SITE.

2. INSTRUMENTATION COMPONENTS SECTION - LISTS ALL HARDWARE ELEMENTS OF THE DATA. COLLECTION EQUIPMENT NOT SUBSEQUENTLY LISTED IN THE MEASUREMENTS SECTION.

3. MEASUREMENTS SECTION - LISTS ALL MEASUREMENTS WHICH ORIGINATE IN A SOLAR HEATING AND COOLING OPERATIONAL SITE WITH APPROPRIATE INFORMATION FOR EACH MEASUREMENT. 
INSTRUMENTATION PROGRAM AND COMPONENTS LIST -- $\frac{\text { DECADE } 80 \text { HOUSE }}{\text { IP } 7933729}$ REV

TABLE OF CONTENTS

PAGE

APPROVAL/REVISION SHEET

INTRODUCTION

N TABLE OF CONTENTS

3

PREAMBLE SECTION

INSTRUMENTATION COMPONENTS SECTION

MEASUREMENTS SECTION 
INSTRUMENTATION. PROGRAM AND COMPONENTS LIST ---

DECADE 80 HOUSE

$\frac{14 / 25 / 77}{\text { REV }}$

IP 7933729

PREAMBLE SECTION 
INSTRUMENTATION PROGRAM AND COMPONENTS LIST:

DECADE 80 HOUSE

IP 7933729

OPERATIONAL SITE IDENTIFICATION

1. SITE NAME: DECADE 80 HOUSE

2. PON:

3. SITE NUMBER: 0022

4. SITE SDASS TELEPHONE NUMBER: $602-29.7-8092$

5. SITE SDAS COMPUTER ADDRESS: 013

6. SITE ADDRESS 7779 North Vie Piccolina

7. LOCATION: TUCSON, AZ 85704

8. SYSTEM DESIGNER:_Copper Development Association

9. SYSTEM TYPE: Solar Heating and cooling

10. FLUID MEDIA: Water 
INSTRUMENTATION PROGRAM AND COMPONENTS LIST:

1. SOLAR HEATING AND COOLING INSTRUMENTATION INSTALLATION GUIDELINES, OCTOBER 1, 1977.

2. [X] SITE DATA ACQUISITIION SUBSYSTEM PERFORMANCE SPECIFICATION, MAY 14, 1976, IBM NO. 7932905.

[ ] SITE DATA ACQUISITION SUBSYSTEM MODEL II, PERFORMANCE SPECIFICATION, 7934354.

[ ] SITE DATA ACQUISITION PERFORMANCE SPECIFICATION. ACUREX NODEL.

3. CENTRAL: DATA PROCESSING SOFTHARE PERFORMANCE SPECIFICATION, JULY. 28, 1976, IBM HO. 7933251 .

4. THERHALL DATA REQUIREMENTS AND PERFORHANCE EVALUATION PROCEDURES FOR THE NATIONAL SOLAR HEATIIIG ARD COOLIHG DEMOHSTRATION PROGRAM, AUGUST, 1976 (NESIR 76-1137).

5. JUICTIOH BOX PERFORHANCE SPECIFICATION, OCTOBER 26, 1976, IBM NO. 7933446.

6. OII SITE HOHITOR (OSH) OPERATIOA MANUAL; OCTOBER 17. 1977, IBM NO. 7934365. 
INSTRUMENTATION PROGRAM AND COMPONENTS LIST:

DECADE 80 HOUSE

IP 7933729
$02 / 08 / 78$

REV

THE LEGEND FOR THE DATA LISTED IN THE MEASUREMENTS SECTION OF THIS DOCUMENT IS AS FOLLOWS:

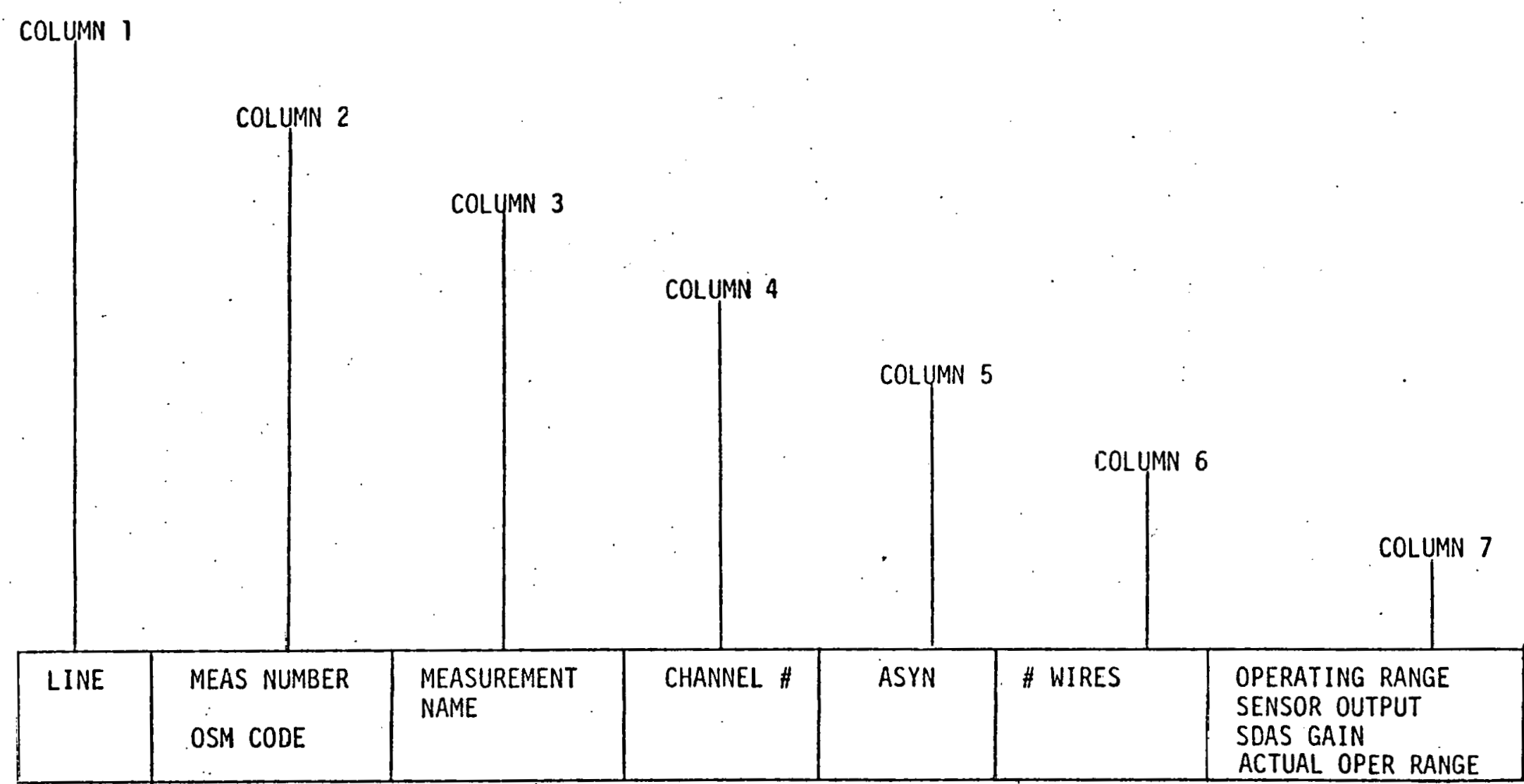




\section{MESSUREIIFHTS LEGEHD (CONTINUED)}

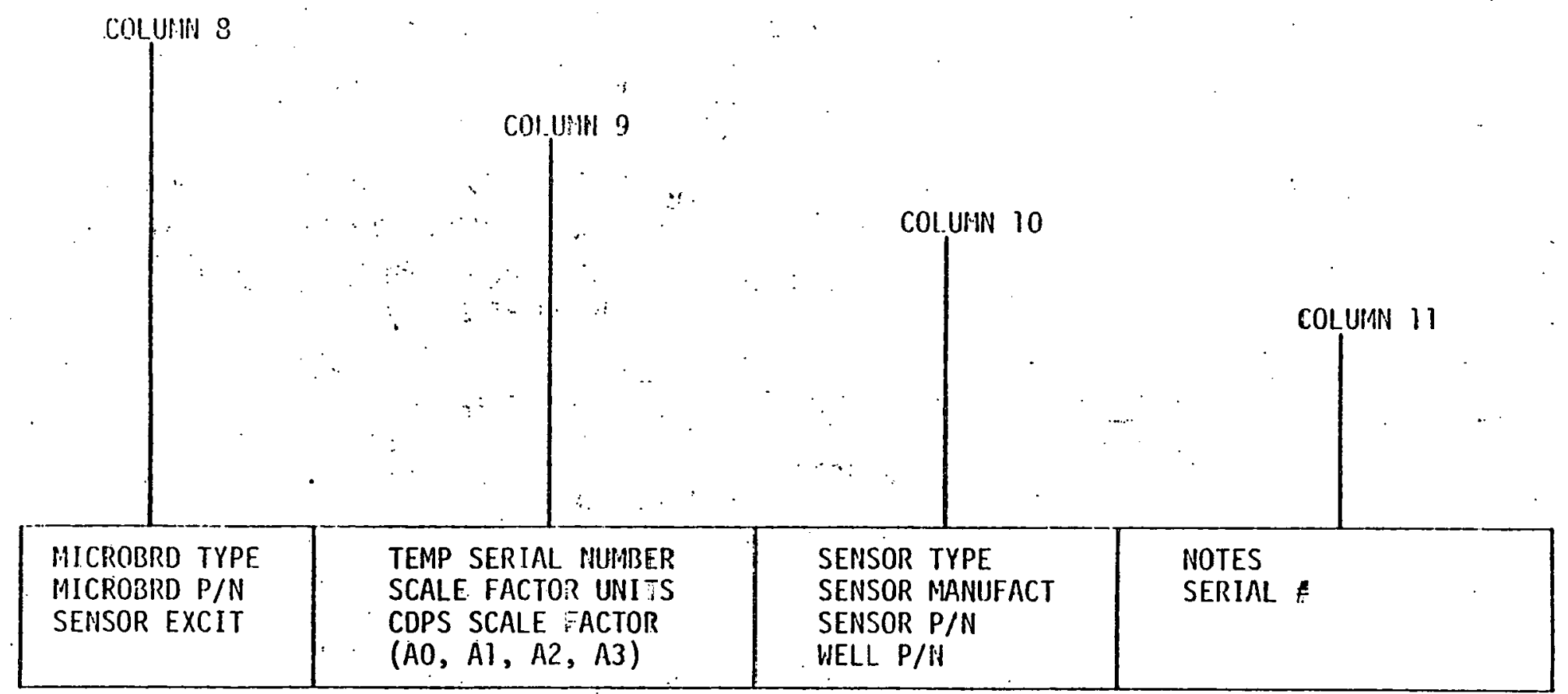

THE COLUMN HEADINGS ARE DEFINED ON THE FOLLOWING SHEETS. 


\section{COLUMN 1. LINE NUMBER}

THIS COLUMN IS USED FOR AUTOMATIC PRINTOUT DATA CONTROL AND LINE IDENTIFICATION.

COLUMIN 2. (MULTIPLE DATA SETS)

THIS COLUMN CONTAINS TWO DATA SETS AS DEFINED BELOW:

MEAS NUMBER. THE FIRST LINE OF THTS COLUMN LISTS EACH MEASUREMENT HHICH IS IDENTIFIED BY A UNIQUE ALPHANUMERIC CODE CONSISTING OF TEN CHARACTERS AS FOLLOWS:

\begin{tabular}{|l|l|l|l|l|}
\hline FIELD NO. & 1 & 2 & 3 & 4 \\
\hline MEASUREMENT NO. & XY & 001 & - & 0001 \\
\hline PARAMETER TYPE & & & \\
PARAMETER SEQUENCE & & \\
SEPARATOR & \\
SITE IDENTIFIER &
\end{tabular}

AN ÁSTERISK (*) FOLLOWING THE MEASUREMENT NUMBER DENOTES A CHANGE FROM THE PREVIOUS RELEASE. OSM CODE. THE SECOND LINE OF THIS COLUMN LISTS THE ON SITE MONITOR SWITCH SETTING TO DISPLAY ENGINEERING UNIT DATA. THIS IS TO BE USED WITH ASSOCIATED DOCUMENT 6 AND THE GENERAL NOTES ON PAGE 16 OF THIS DOCUMENT. 
INSTRUMENTATION PROGRAM AND COMPONENTS LIST -- DECADE 80 HOUSE $\frac{7 / 28 / 77}{\text { IP 7933729 }}$

A. FIELD NO. 1 - PARAMETER TYPE

\begin{tabular}{|c|c|c|c|}
\hline CODE & PARAMETER & UNITS. & ABB. \\
\hline $\begin{array}{l}\text { D } \\
D\end{array}$ & $\begin{array}{l}\text { WIND DIRECTION } \\
\text { SWITCH }\end{array}$ & $\begin{array}{l}\text { DEGREES - AZIMUTH } \\
\text { DEGREES - ON/OFF }\end{array}$ & $\begin{array}{l}\text { DEG } \\
\text { DEG }\end{array}$ \\
\hline EP & ELECTRICAL POWER & KILOWATTS & $\mathrm{KW}$ \\
\hline $\begin{array}{l}F \\
F\end{array}$ & $\begin{array}{l}\text { FLOWRATE (NATURAL GAS) } \\
\text { FLOWRATE (FUEL OIL) }\end{array}$ & $\begin{array}{l}\text { FEET }^{3} \text { /MINUTE } \\
\text { GAL/MINUTE }\end{array}$ & $\begin{array}{l}\text { SCFM } \\
\text { GPM }\end{array}$ \\
\hline I & SOLAR FLUX & BTU PER FOOT ${ }^{2} \times$ HOUF & $B T U / F T^{2}-H R$ \\
\hline RH & HUMIDITY ' & PERCENT & PER \\
\hline SP & SPARE $\quad \because:$ & N/A & N/A \\
\hline$T$ & TEMPERATURE & DEGREES FAHRENHEIT & DEG $F$ \\
\hline TD & DIFFERENTIAL TEMPERATURE & DEGREES FAHRENHEIT & DEG F/DT \\
\hline$H$ & $\begin{array}{l}\text { FLOWRATE (LIQUID) } \\
\text { FLOWRATE (AIR) }\end{array}$ & $\begin{array}{l}\text { GALLONS PER MINUTE, } \\
\text { CUBIC FEET PER MINUTE }\end{array}$ & $\begin{array}{l}\text { GPM } \\
\text { CFM }\end{array}$ \\
\hline v & WIND SPEED & MILES PER HOUR & MPH \\
\hline PD & DIFFERENTIAL PRESSURE & POUNDS PER SQ. INCH & PSI \\
\hline
\end{tabular}


INSTRUMENTATION PROGRAM AND COMPONENTS LIST --- $\frac{\text { DECADE } 80 \text { HOUSE }}{\text { IP 7933729 }} \frac{4 / 25 / 77}{\text { REV }}$

B. FIELD NO. 2 - PARAMETER SEQUENCE

A NUMERIC GROUPING WHICH DESIGNATES THE SEQUENTIAL NUMBER OF A MEASUREMENT WITHIN EACH SUBSYSTEM. THE SEQUENTIAL NUMBER OF EACH MEASUREMENT CONFORMS TO THE PATTERN E.STABLISHED IN FIGURE 3-1 OF SHC-1006. SEQUENTIAL NUMBER ALLOCATIONS ARE AS FOLLOWS:

NUMERIC SEQUENCE

001-099

100-199

200-299

300-399

400-499

$500-599$

$600-699$

C. FIELD NO. 3 - SEPARATOR

FOR NUMERIC CLARITY.

D. FIELD NO. 4 - SITE IDENTIFIER

A NUMERIC GROUPING WHICH DESIGNATES THE SITE IN WHICH THE MEASUREMENT IS LOCATED.

\section{SUBSYSTEM}

CLIMATOLOG ICAL COLLECTOR

THERMAL STORAGE

DOMESTIC HOT WATER

SPACE HEATING

SPACE COOLING

BUILDING/LOAD 
INSTRUMENTATION PROGRAM AND COMPONENTS LIST $--\frac{\text { DECADE } 80 \text { HOUSE }}{\text { IP } 7933729}$

COLUMN 3. MEASUREMENT NAME

THIS COLUMN LISTS THE MEASUREMENT NAME USED. TO DESCRIBE THE DATA SOURCE.

COLUMN 4. CHANNEL \#

THIS COLUMN DEFINES THE SDAS CHANNEL $\because$ ASS IGNED TO EACH MEASUREMENT (2 - 48 ). CHANNEL 1 IS RESERVED FOR AN SDAS INTERNAL CALIBRATIOH OFFSET MEASUREMENT.

$\omega$ COLUMN 5. ASYN

THIS COLUMN DEFINES EACH MEASUREMENT WHICH IS ASYNCHRONOUSLY SAMPLED AND IS INDICATED BY THE LETter "A". THESE MEASUREMENTS ARE .SAMPLED EACH 32 SECONDS WITH JHE AVERAGED VALUE PER 5 MINUTES MAINTAINED FOR TEANSMISSIOM. SYNCHRONOUSLY SAMPLED MEASUREMENTS ARE READ ONCE PER 5 MINUTES AND ARE IDENTIFIED BY THE "-" SYMBOL.

COLUMN 6. \#WIRES

THIS COLUMN DEFINES THE NUMBER OF WIRES FER" CHANNEL USED IN THE SDAS. EITHER 3 WIRE OR 2 WIRE CHANNELS ARE AVAILABLE VIA A PRE-DEFINED CONFIGURATION. 
THIS COLUMN CONTAINS FOUR DATA SETS AS DEFINED BELOW:

OPERATING RANGE - THE FIRST LINE OF THIS COLUMN DESCRIBES THE OPERATING RANGE OF THE PARAMETER IW ENGINEERING UNITS.

SENSOR OUTPUT RANGE - THE SECOND. LINE OF THIS COLUMN DESCRIBES THE OUTPUT RANGE IN VOLTS OF THE SENSOR.

SOAS GAIN - THE THIRD LINE OF TIIIS COLUIMN DESCRIBES. THE SOAS GAIN SELECTED FOR EACH CHANNEL.

ACTUAL OPER RANGE - THE-FOURTH LINE OF THIS COLUMN IS APPL-ICABLE TO ABSOLUTE TEMPERATURES ONLY (AFTER CORRECTION COEFFICIENTS ARE APPLIED.)

COLUINI 8. (MULTIPLE DATA SETS)

THIS COLUHN CONTAINS THREE DATA SETS AS DEFINED BELOH:

HICROBRD TYPE - THE FIRST LINE OF TIIIS COLUHN DESCRIBES THE TYPE OF MICROBOARD USED FOR SIGNAL COHDITIONIHG OF. THE EMPLOYED SDAS CHANNEL. .

HICROBRD P/N - THE SECOND LINE OF TIIIS COLUMN DESCRIBES THE PART NUMBER OF THE MICROBOARD USED FOR SIGHAL CONDITIONING OF THE EMPLOYED SDAS CIIANNEL. A NON-DEFINED MICROBOARD P/N INDICATES THAT THIS CHANNEL SHARES A HICROBOARD WITH ANOTHER CHANNEL WHICH WILL DEFINE THE P/N.

SENSOR EXCIT - THE THIRD LINE OF THIS COLUMH DESCRIBES THE EXCITATION REQUIREMENTS FOR EACH SENSOR, IF REQUIREU. 
THIS COLUMN CONTAINS THREE DATA SETS AS DEFINED BELOW:

TEMP SERIAL \#- THE FIRST LINE OF THIS COLUMN DESCRIBES THE TEMPERATURE PROBE SERIAL NUMBER (IF AVAILABLE).

SCALE FACTOR UNITS - THE SECONC LINE OF THIS COLUMN DESCRIBES THE ENGINEERING UNITS MAINTAINED IN THE COPS FOR EACH MEASURENENT.

CDPS SCALE FACTOR -- THE THIRD AND FOURTH LINES OF THIS COLUMM DESCRIBE THE NUMERIC SCALE FACTOR(S) USED IM. THE CENTRAL DATA PROCESSINIF SYSTEM (CDPS). TO CONVERT EACH MEASUREMENT TÒ ENGINEERING UNITS.

COLUHA 10. (HULTIPLE DATA SETS):

THIS COLÜNN CONTAINS FOUR DATA SETS AS DEFINED BELOW:

SENSOR TYPE - THE FIRST LINE OF THIS COL.UIN LISTS THE TYPE (NAHE) OF THE EMPLOYED SENSOR.

SEHSOR HANUFACT - THE SECOND LIHE OF THIS COLUMN LISTS THE SENSOR MANUFACTURER.

SENSOR P/N - THE THIRD LINE OF THIS COLUMH LISTS THE PART NUMEER OF THE. SENSOR.

WELL P/N - THE FOURTH LINE OF THIS COLUHN DESCRIBES TIIE PART HUMBER OF A THERMAL WELL. IF REQUIRED FOR THE DEFIHED SEIISOR. 


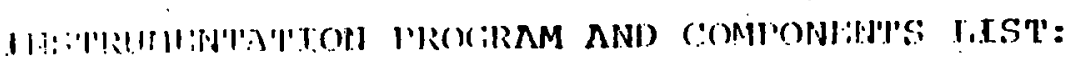

DECADE 80 IIOUSE

COLUMN 11. (IIUL.TIPIE DATA SETS)

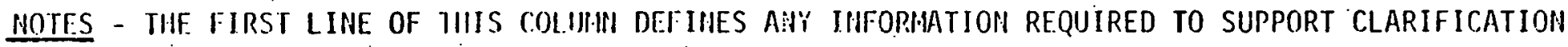
OF: THE MEASUREHENT.

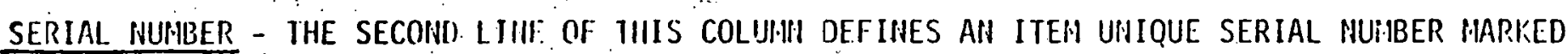
BY TIIF MANUFACTUIRER. 
NOTE 1 - DATA NOT CURRENTLY DEFINED.

NOTE 2 --ENGINEERING UNIT VALUES MUST BE CALCULATED USIHG COUNTS \& SCALE FACTORS.

NOTE 3 - LIQUID FLOW WITHIN $\pm 5 \%$ OF DISPLAYED VALUE.

NOTE 4 - INSULATION WITHIN \pm 5 BTU OF OISPIAYËD VALUE.

NOTE 5 - POWER MEASUREMENT RANGE VALUES \& SCALE FACTORS ARE HALVED DUE TO FOUR TURNS THRU TRANSDUCERS.

NOTE 6 - PONER MEASUREMENT RANGE VALUES \& SCALE FACTORS ARE REDUCED DUE TO MULTIPLE TURNS THRU TRANSDUCERS.

NOTE 7 - VALUES APPEAR ON ATTACHED PAGES AT THE REAR OR END OF THESE LISTINGS. 
INSTRUMENTATION PROGRAM AND COMPONENTS LIST: DECADE 80 HOUSE

IP7933729

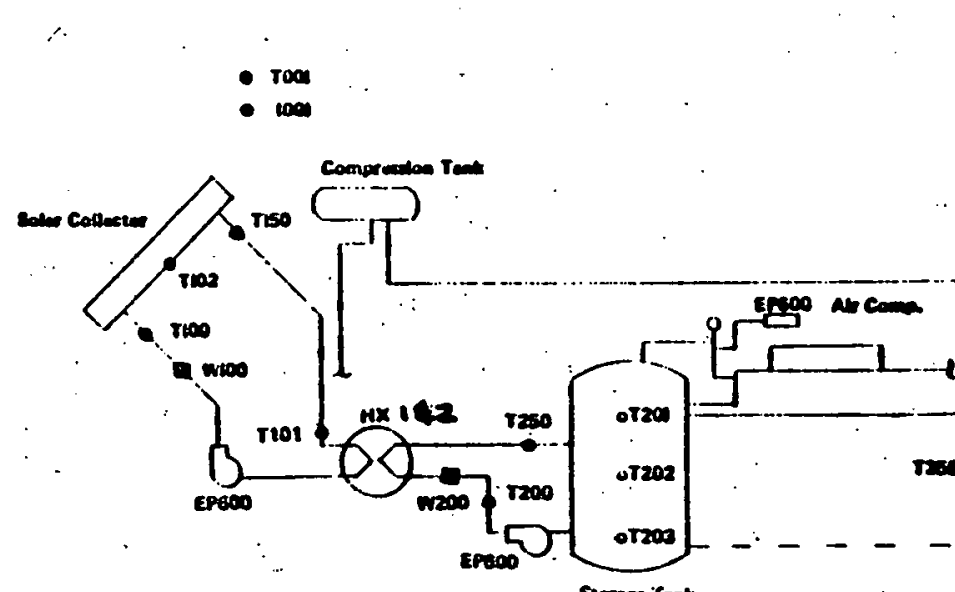

$\underset{w}{\omega}$

SCMEMATIC DEPICTS SOLAR ASFISTEO SYSTEMS FOR DOAESTIC MOT WATEA, SPACE HEATING AMD GPACE ELE. AND GAS BOILER LHOUID SYSTEM: COLLECTOA AREA- $1823 \mathrm{~h}^{2}$.

LIOUID SYSTEM: COLLECTO
STORAGE CAP- 300 OQD.I.

$\underset{\omega}{\omega}$
$6 / 26 / 78$
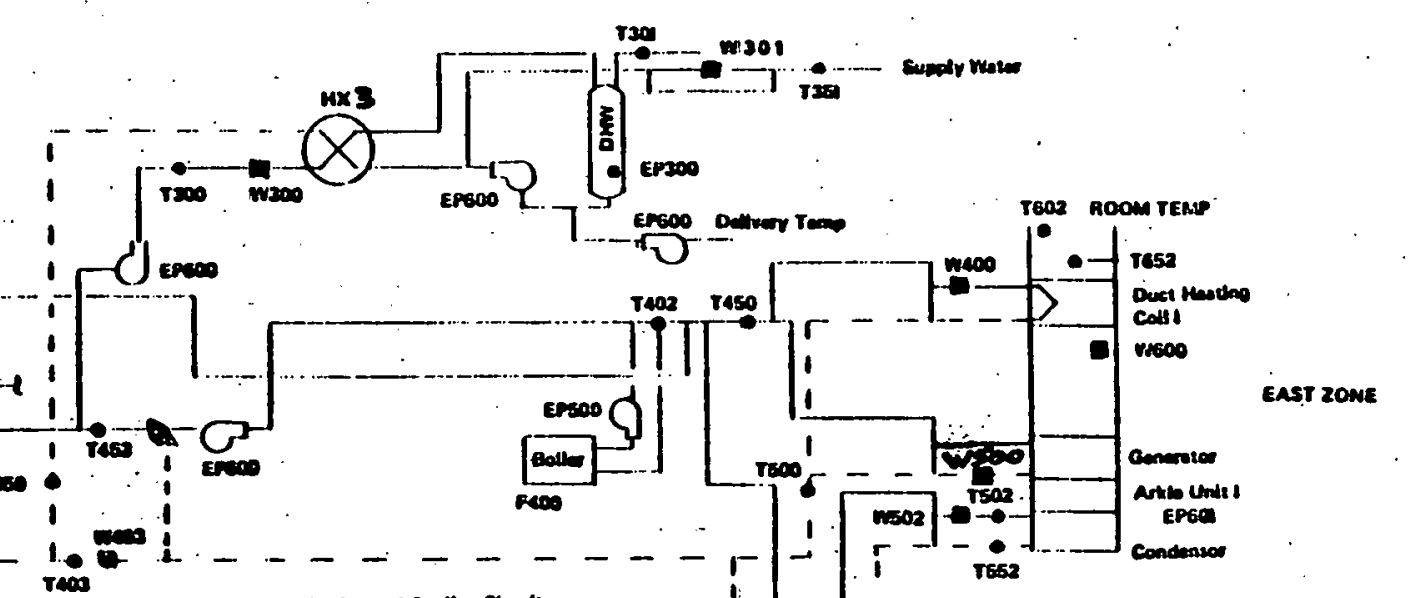
$\underset{\substack{N \\ N}}{N} \mid$

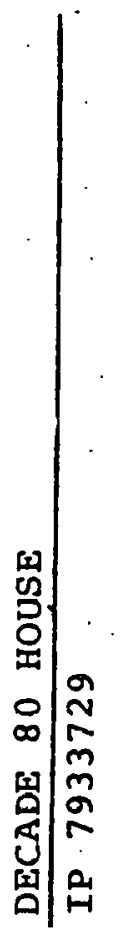

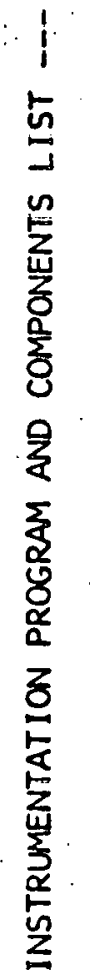

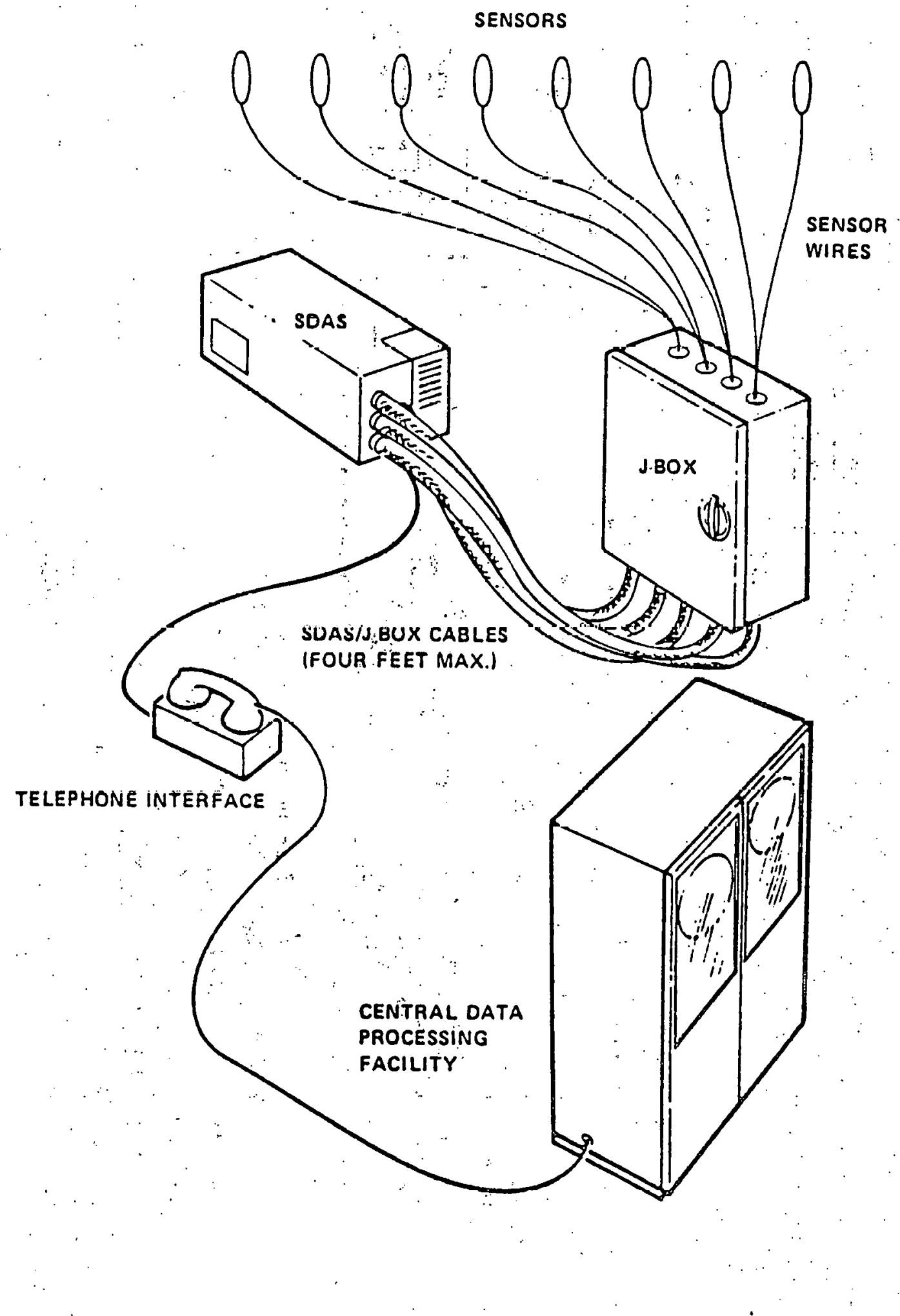

DATA COLLECTION SYSTEM 
INSTRUMENTATION COMPONENTS SECTION 
INSTRUMENTATION PROGRAM AND COMPONENTS LIST -- DECADE 80 HOUSE

EQUIPMENT NAME

JUNCTION BOX

CABLES (J-BOX TO SDAS)

NO. 1

N0. 2 .

No. 3

NO: 4

NO. 5

SDAS
PART NUMBER

\#1

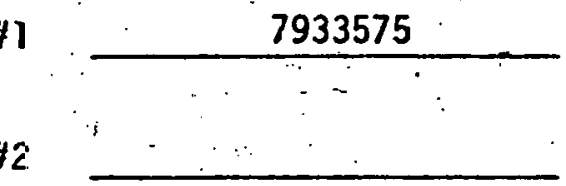

$\# 2$

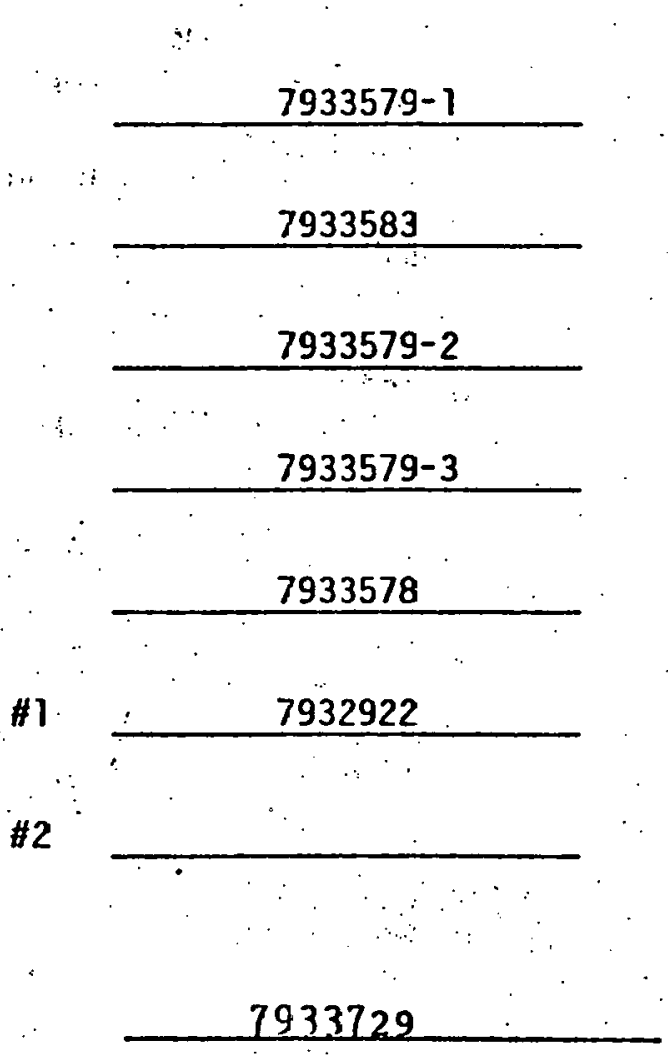

$\# 1$

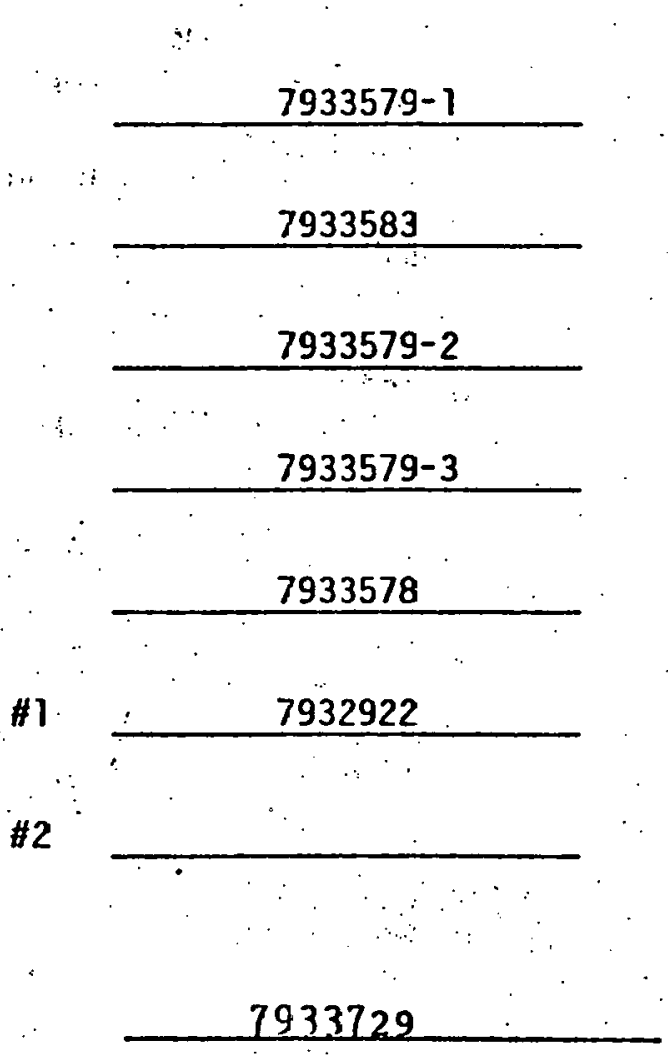

$\# 2$

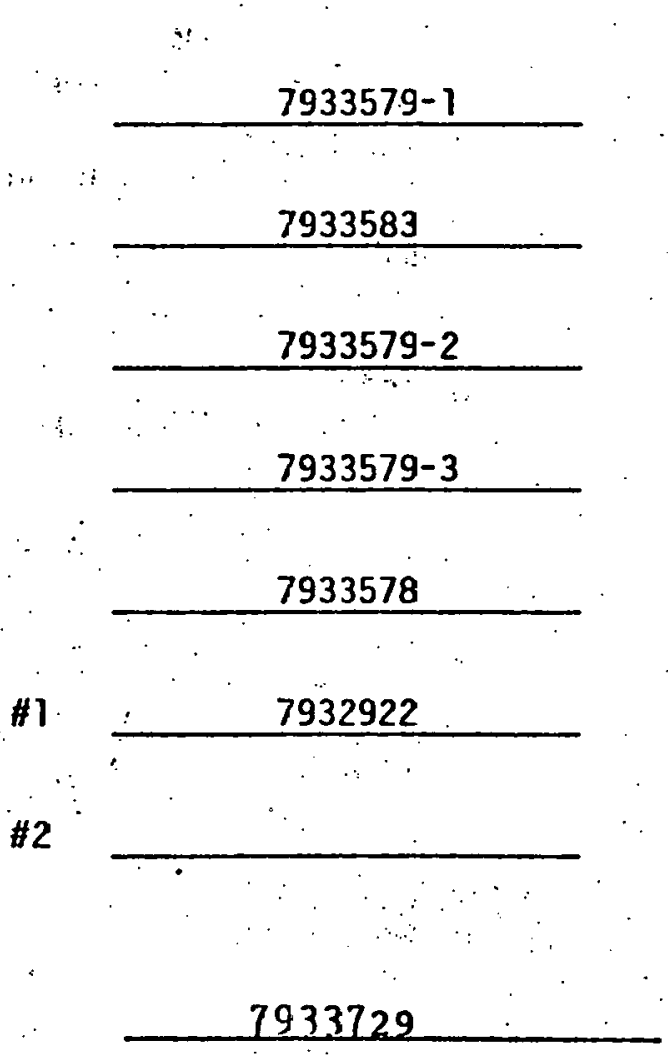

7933729

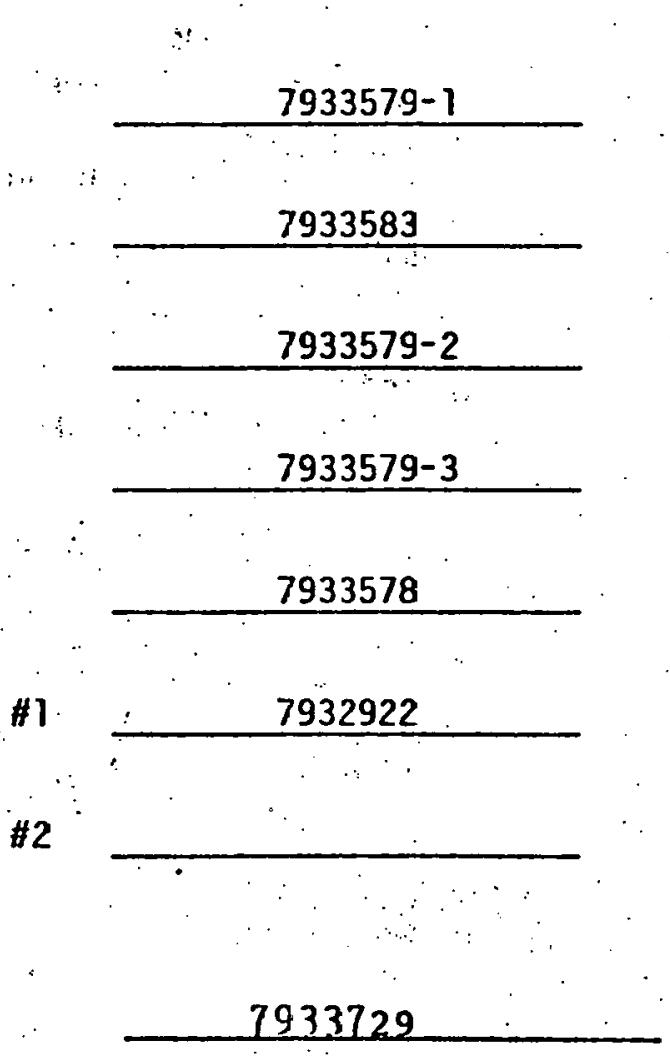

SERIAL NUMABER

036
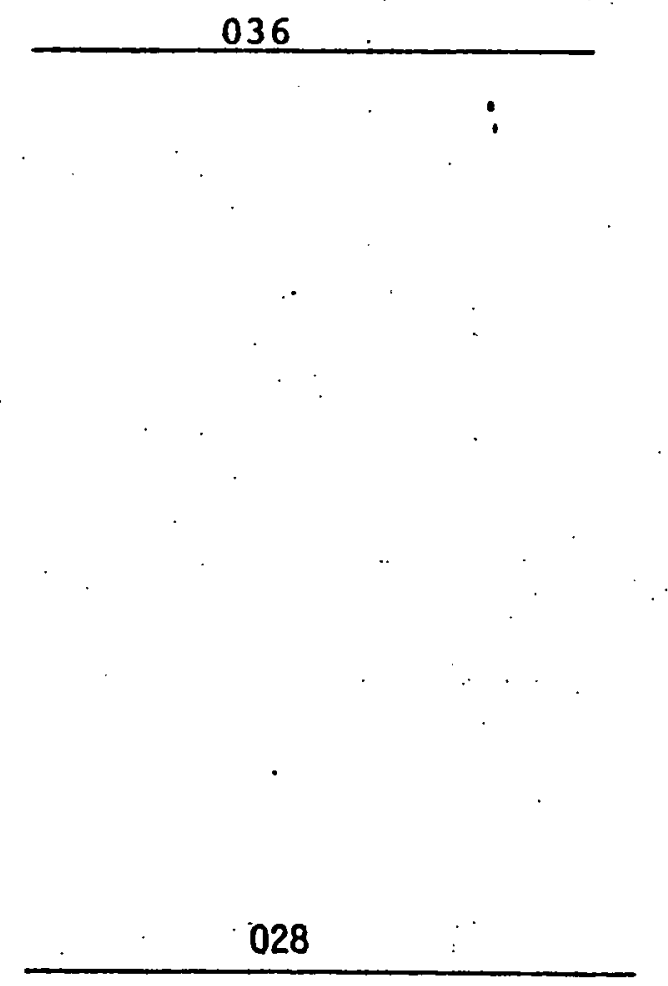

IBM DRAWING NUMBER 
INSTRUMENTATION PROGRAM AND COMPONENTS LIST --- $\frac{\text { DECADE } 80 \text { HOUSE }}{\text { IP } 7933729} \frac{4 / 25 / 77}{\text { REV }}$

MEASUREMENTS SECTION 
INSTRUMENTATION PROGRAM AND COMPONENTS LIST --- DECADE 80 HOUSE

MEASUREMENT SUPMARY

PARAMETER

WIND DIRECTION

ELECTRICAL POWER

FLOWRATE (NATURAL GAS)

SOLAR FLUX

HUMIDITY

SPARE

TEMPERATURE

DIFFERENTIAL TEMPERATURE

FLOWRATE. (LIQUID/AIR)

WIND SPEED
NUMBER

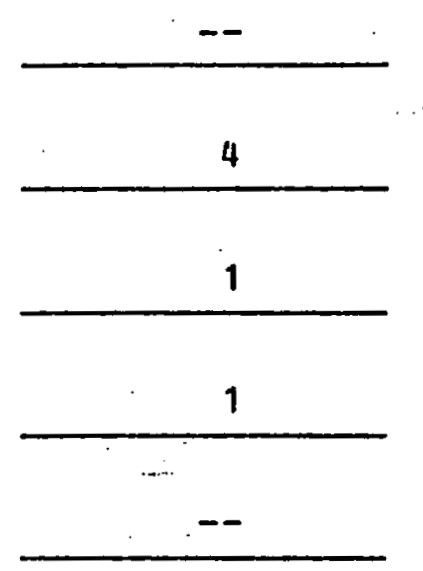

(1)

28

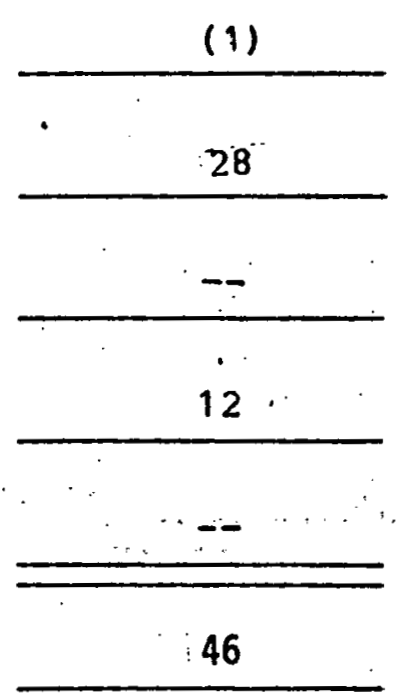

TOTAL 


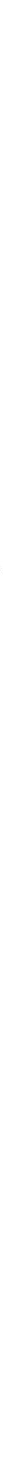


RFPIRT PY CI:ANNFL ASSIGNMENT

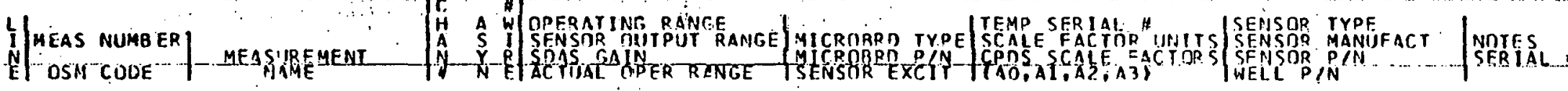
$1150-0022$ COLL
$10-3301450$
PRT
(Tolon)

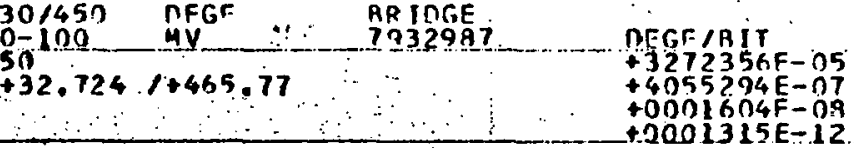

5.

1003

$\because \cdots$

F203115

$\begin{array}{ll}7 & 7 \\ \text { I } & 9500-00 \\ 9 & 1142\end{array}$

PG,PID, COOLING

11: 2 of 0

STRAIGHT
T932985

KH/RI T

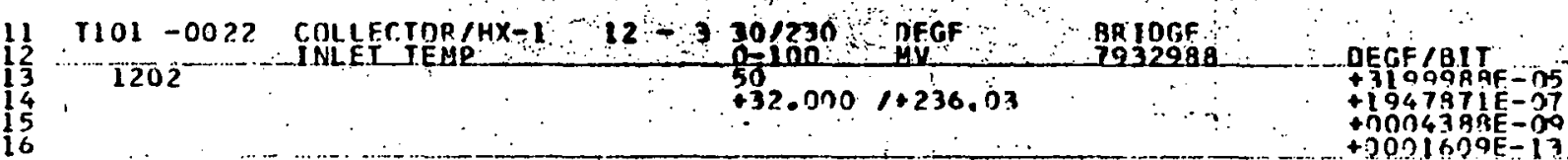

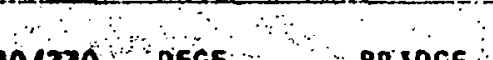

+3029325E-07

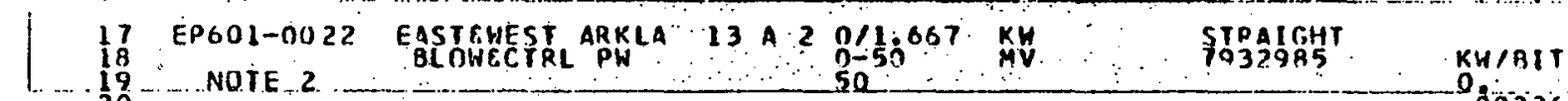

KH/BIT
0 Oกं326IT

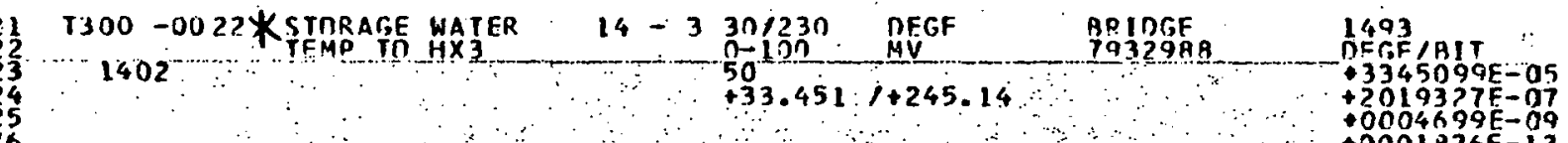

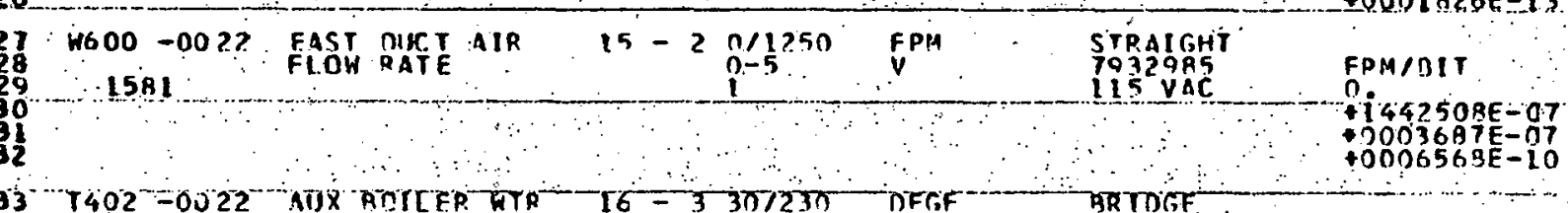

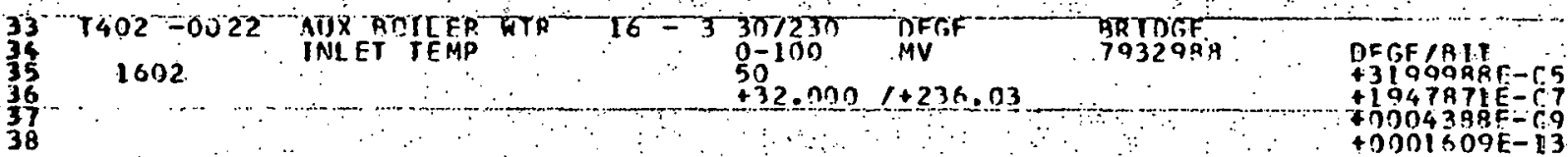

WATT XNCR

OHIO SEMITRNNICS

PAGE: .... 24........

PRT

553740736
F20311:

\section{WATY XOGR NOTE 6}

OHIO SEMITRONICS

pot

Mincen

$\$ 53 P 40236$
F 2031515

ANEMTIETER

$S T F R R A$
$43 n-?$

- INDIC STP

PRT

MINCR

$\$ 53047 \geq 36$
$F 203415$ 
PFPOET BY CHATHEL ASSISNHENT

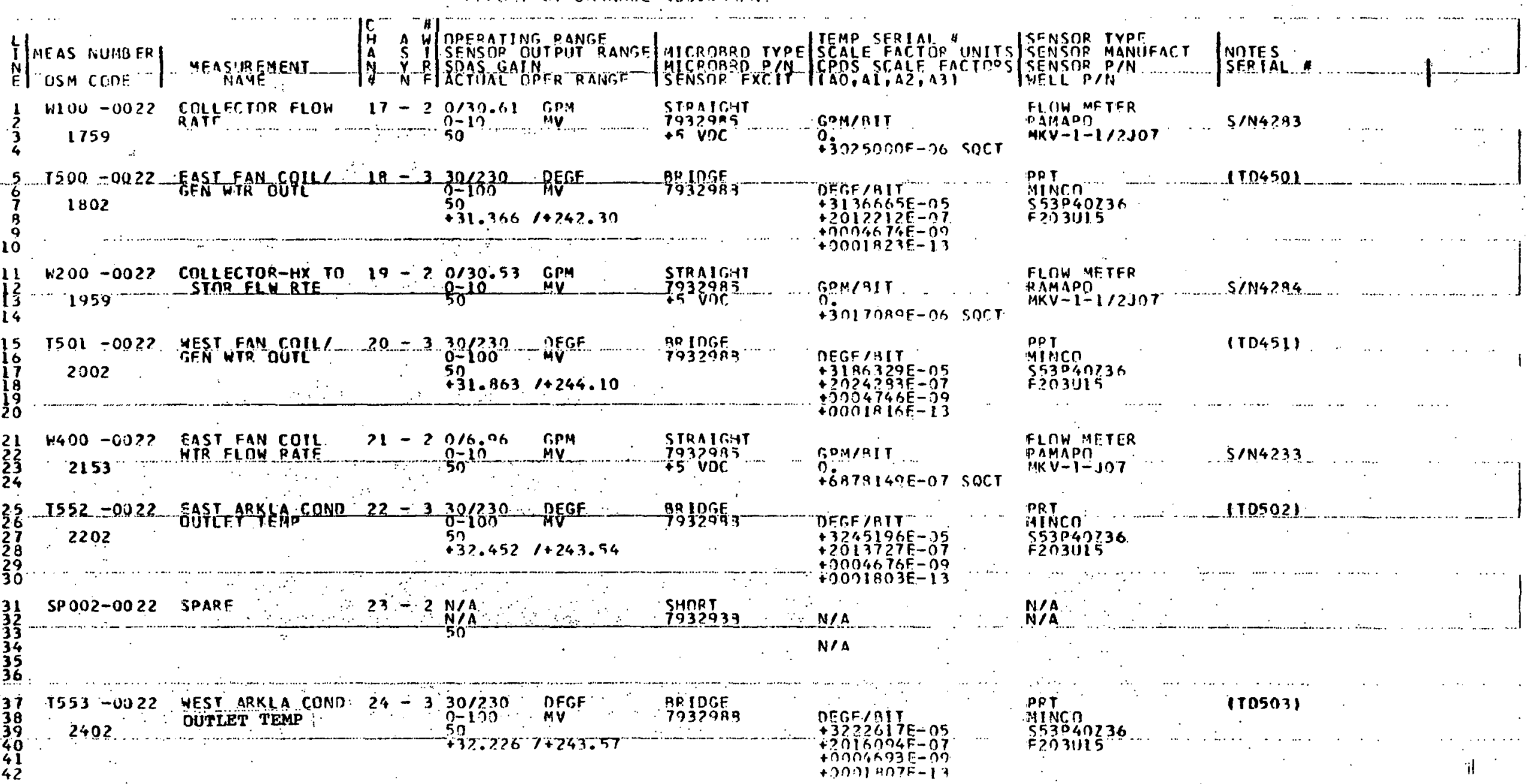




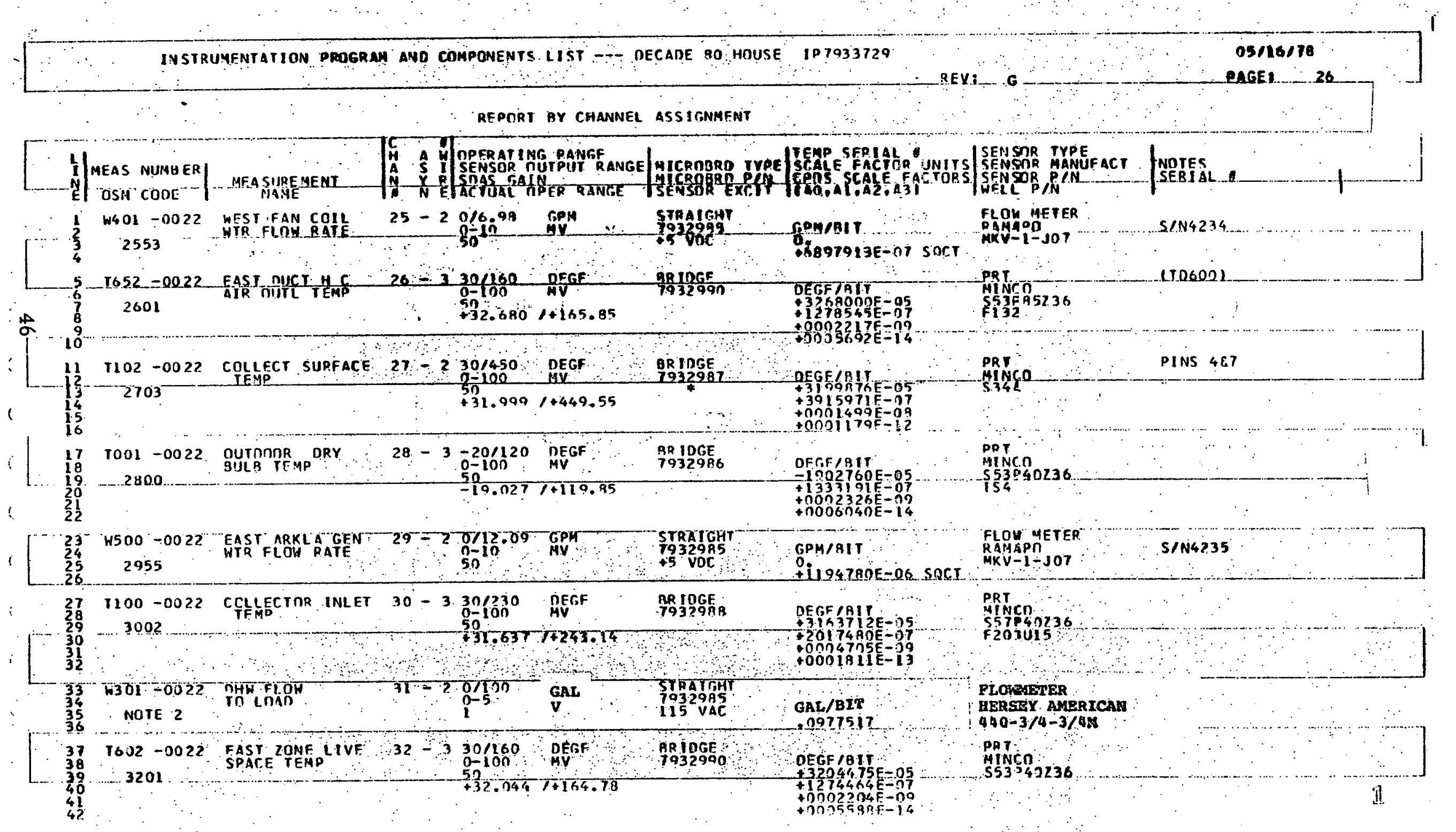


REPIRT OY CHANNEL ASSIGNMENT

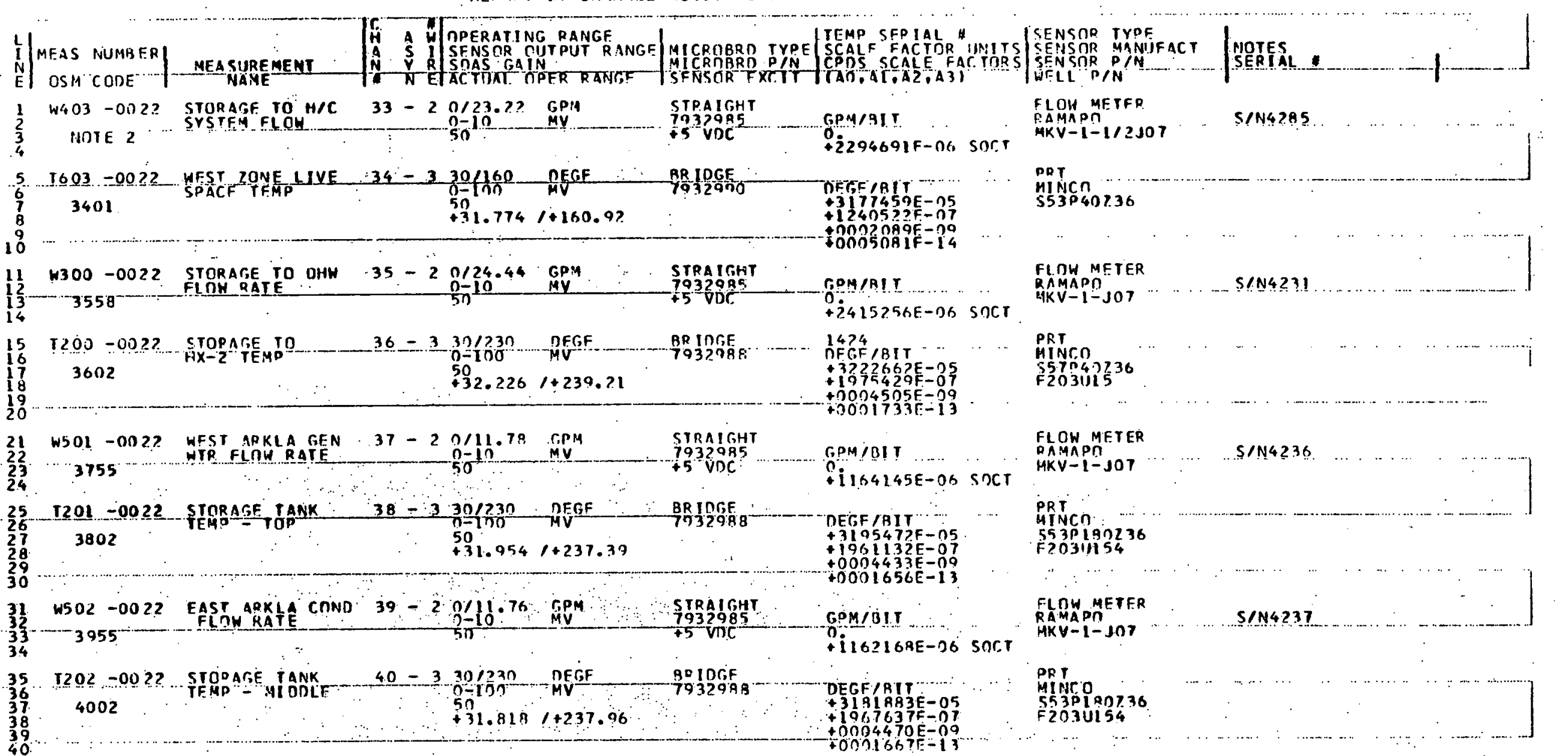




\section{REPOFT AY CHANNEL ASSITINMENT}

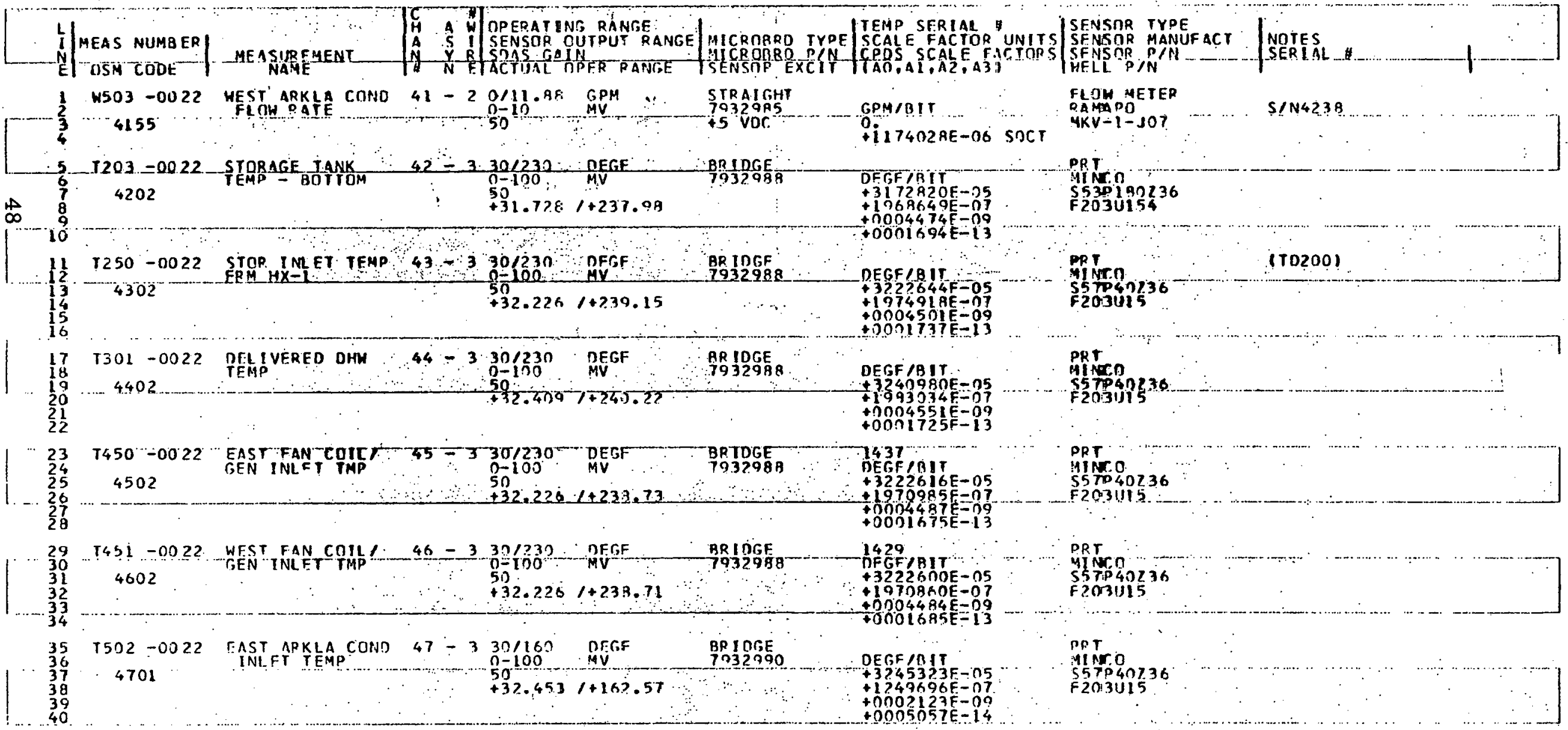




\section{RFPIRT AY CHANAEL ISSISNMENT}

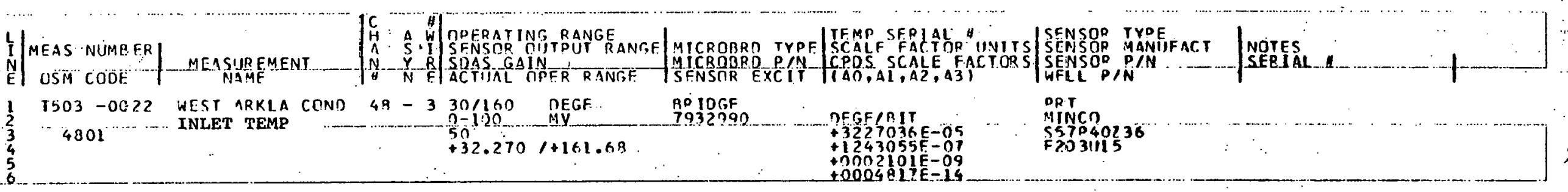




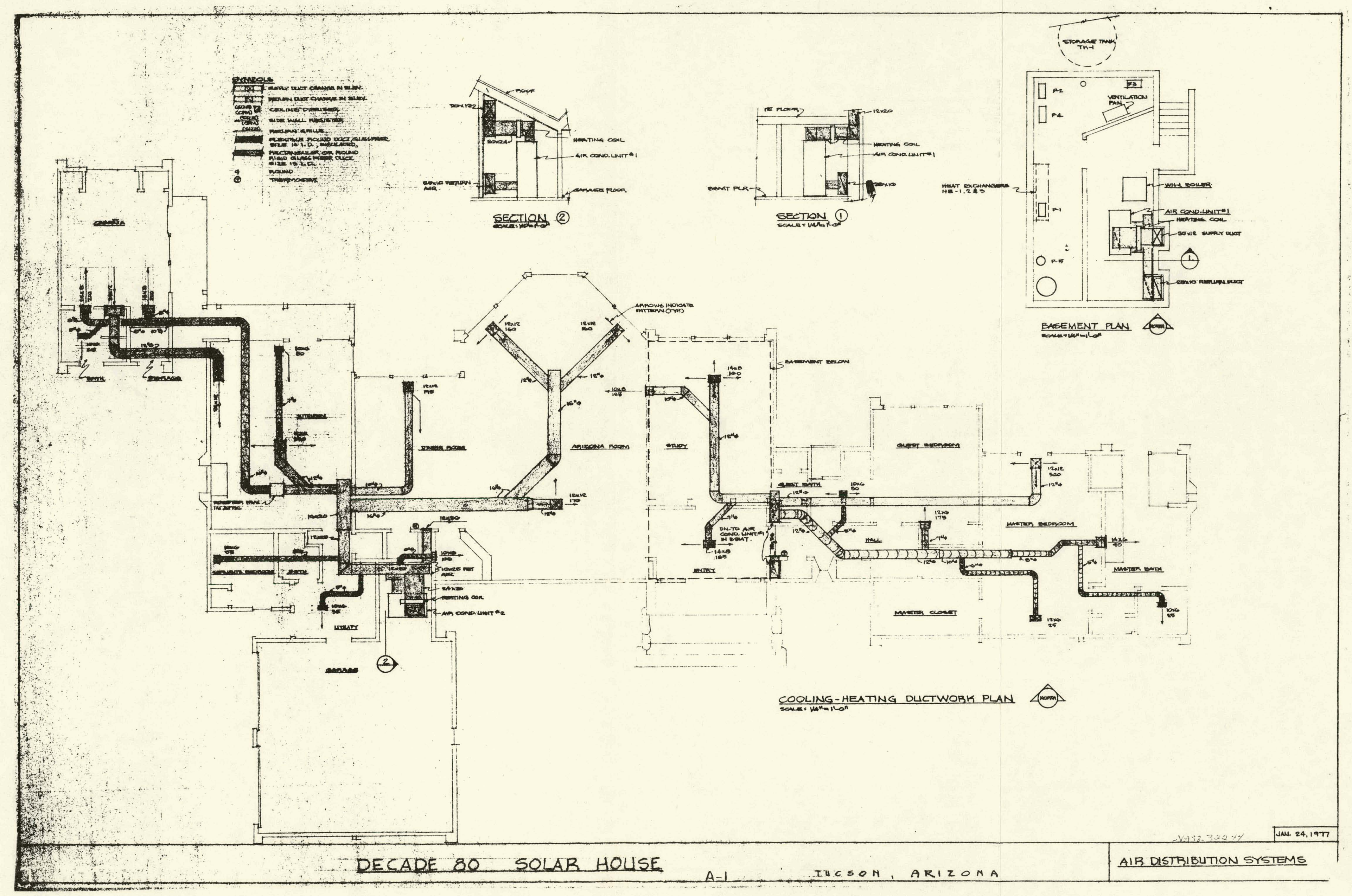




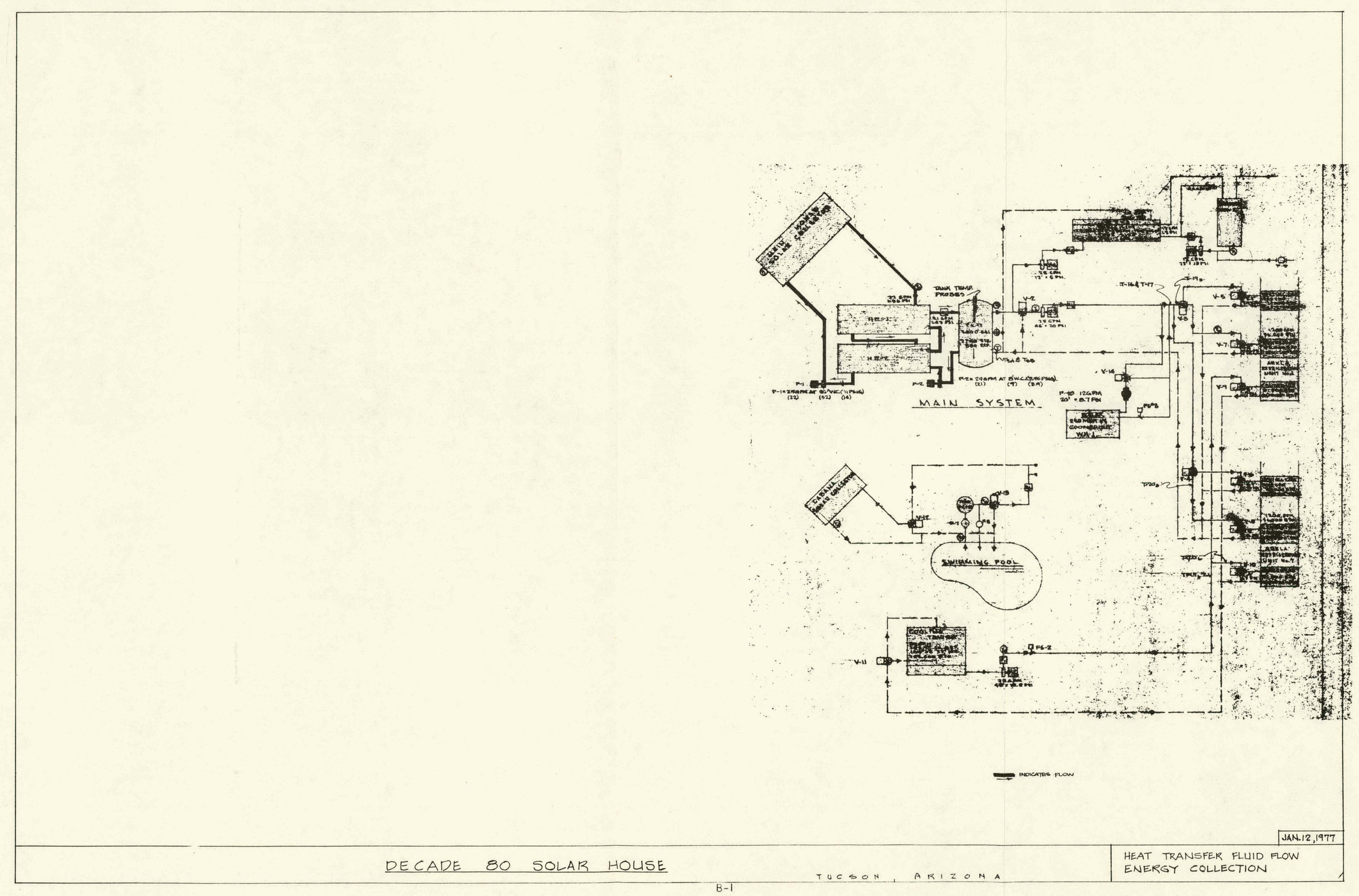




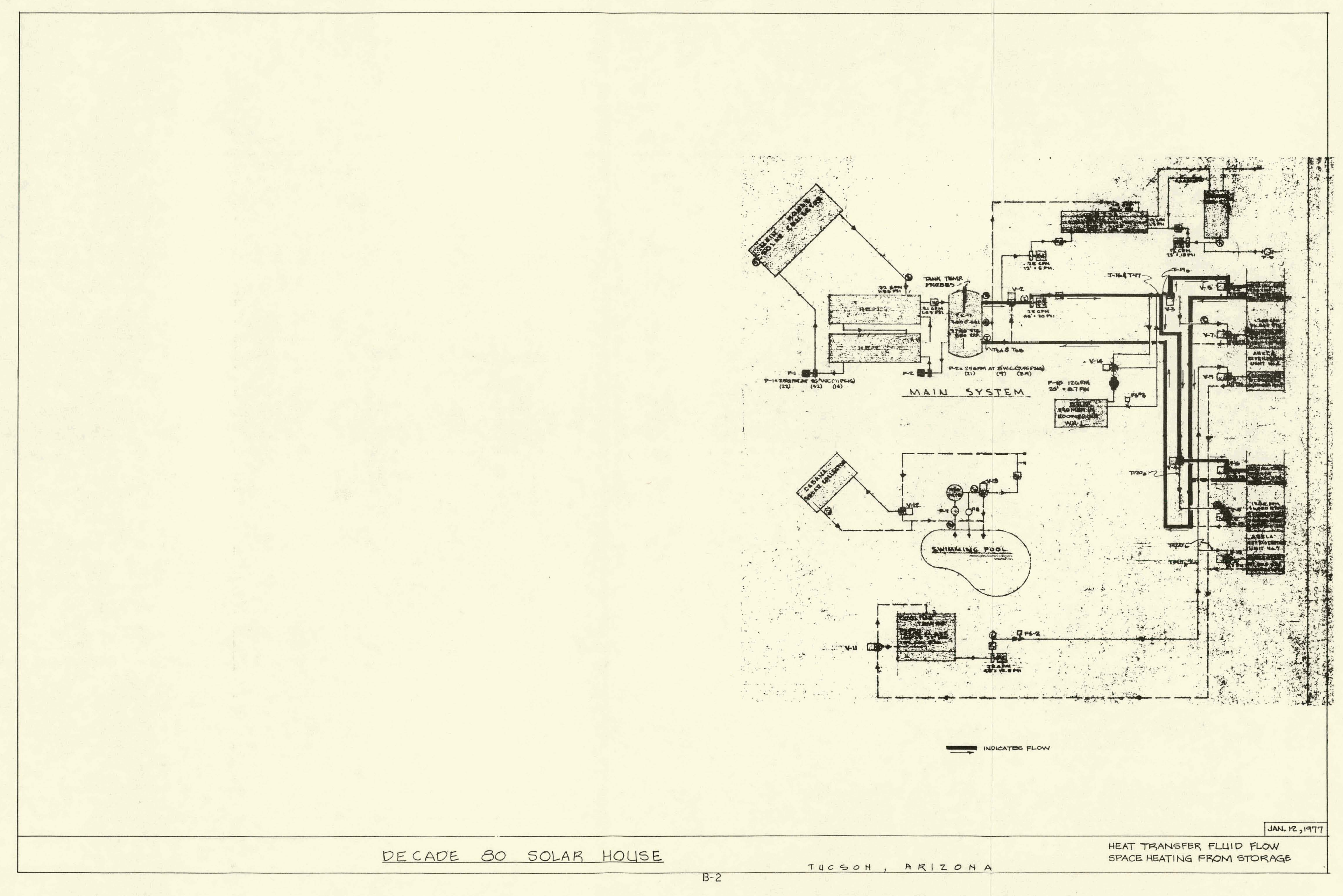




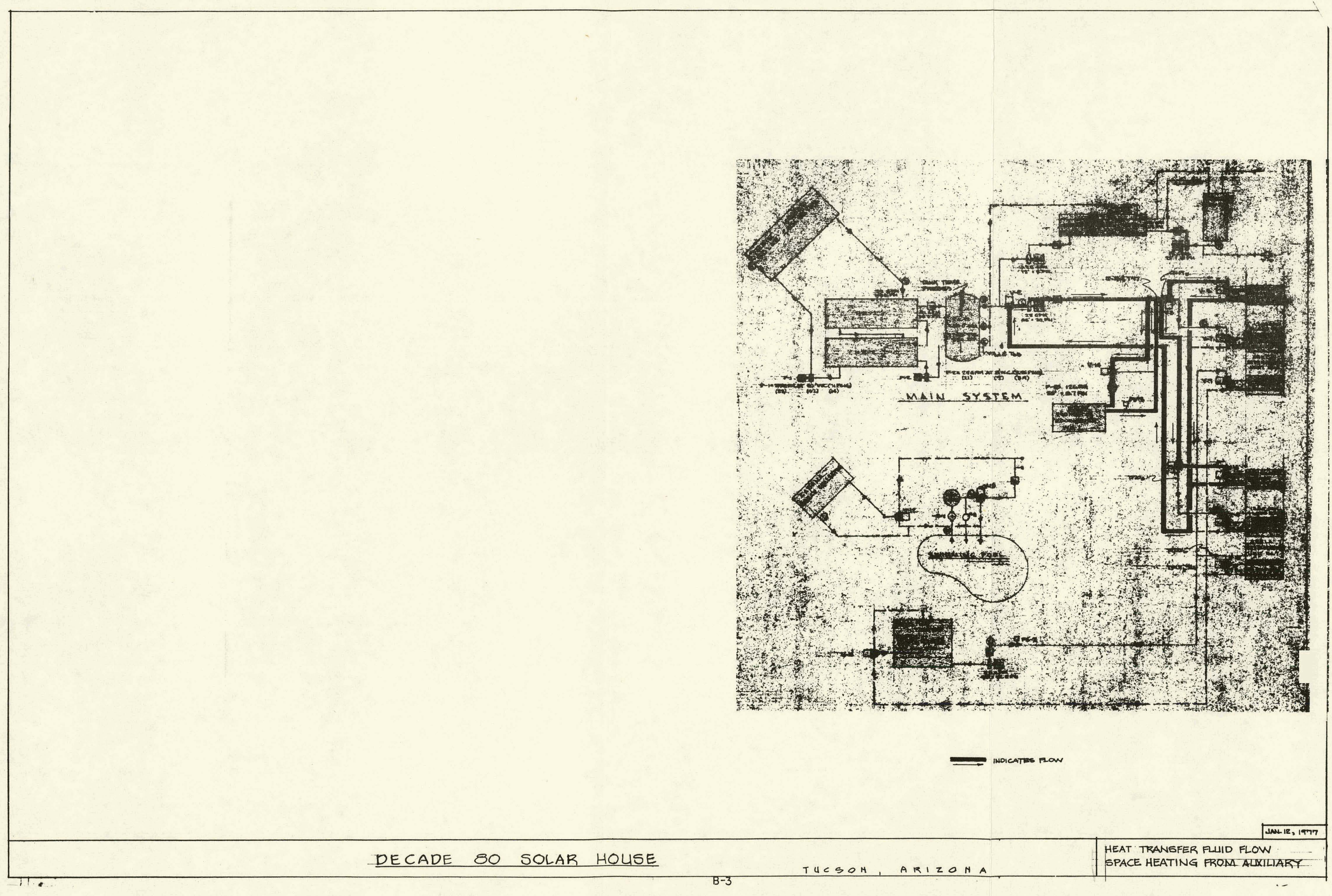




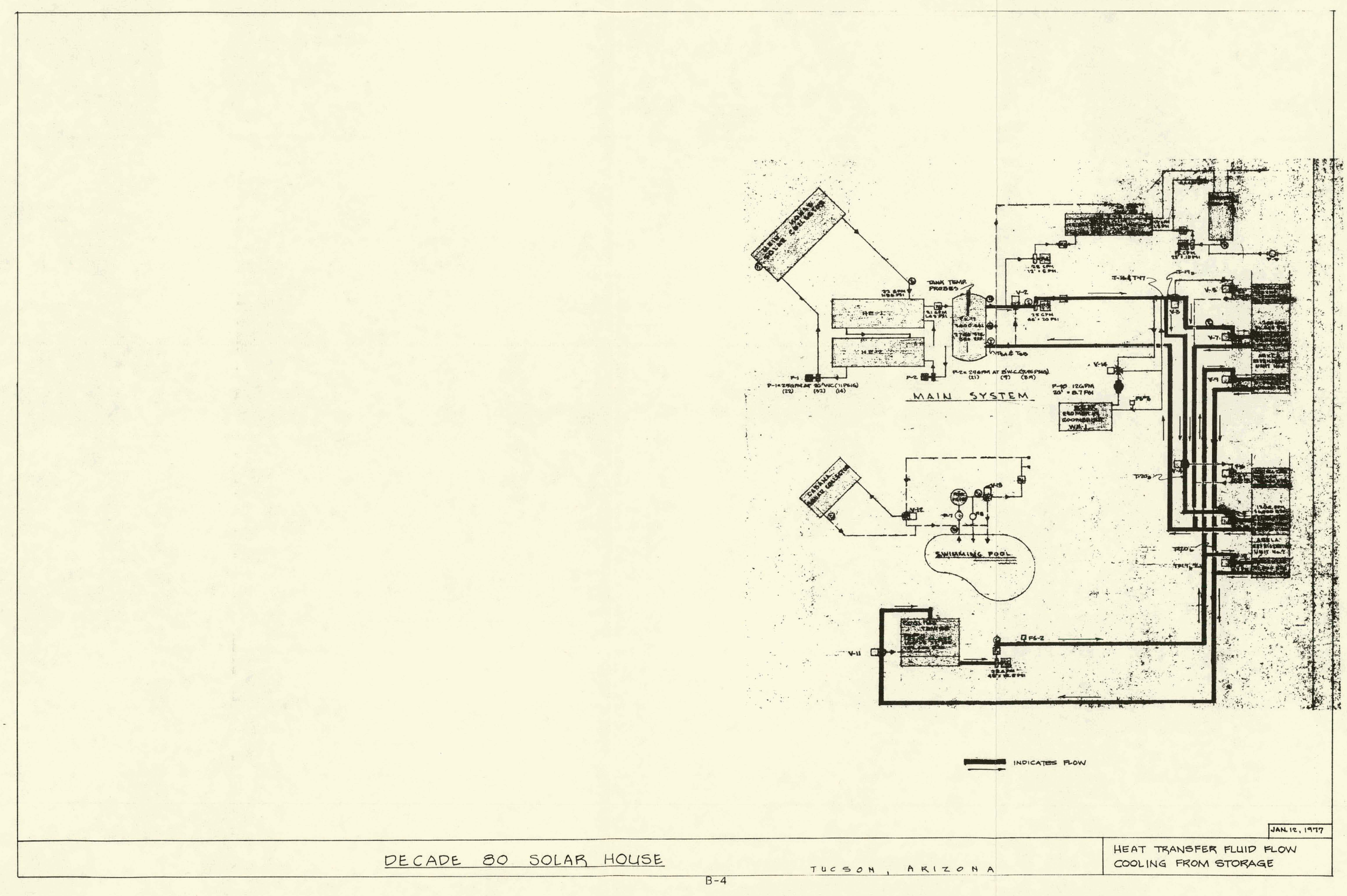




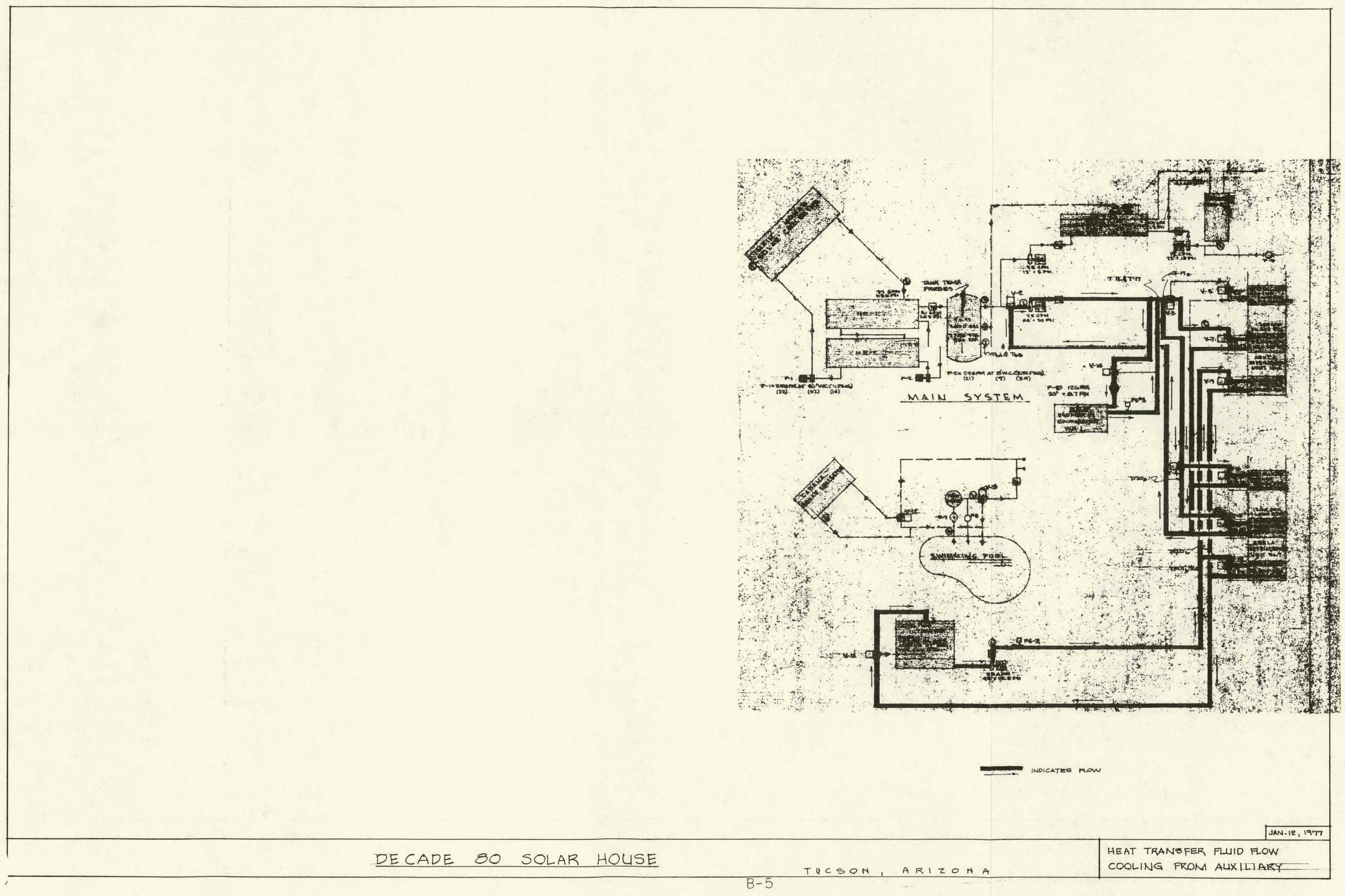




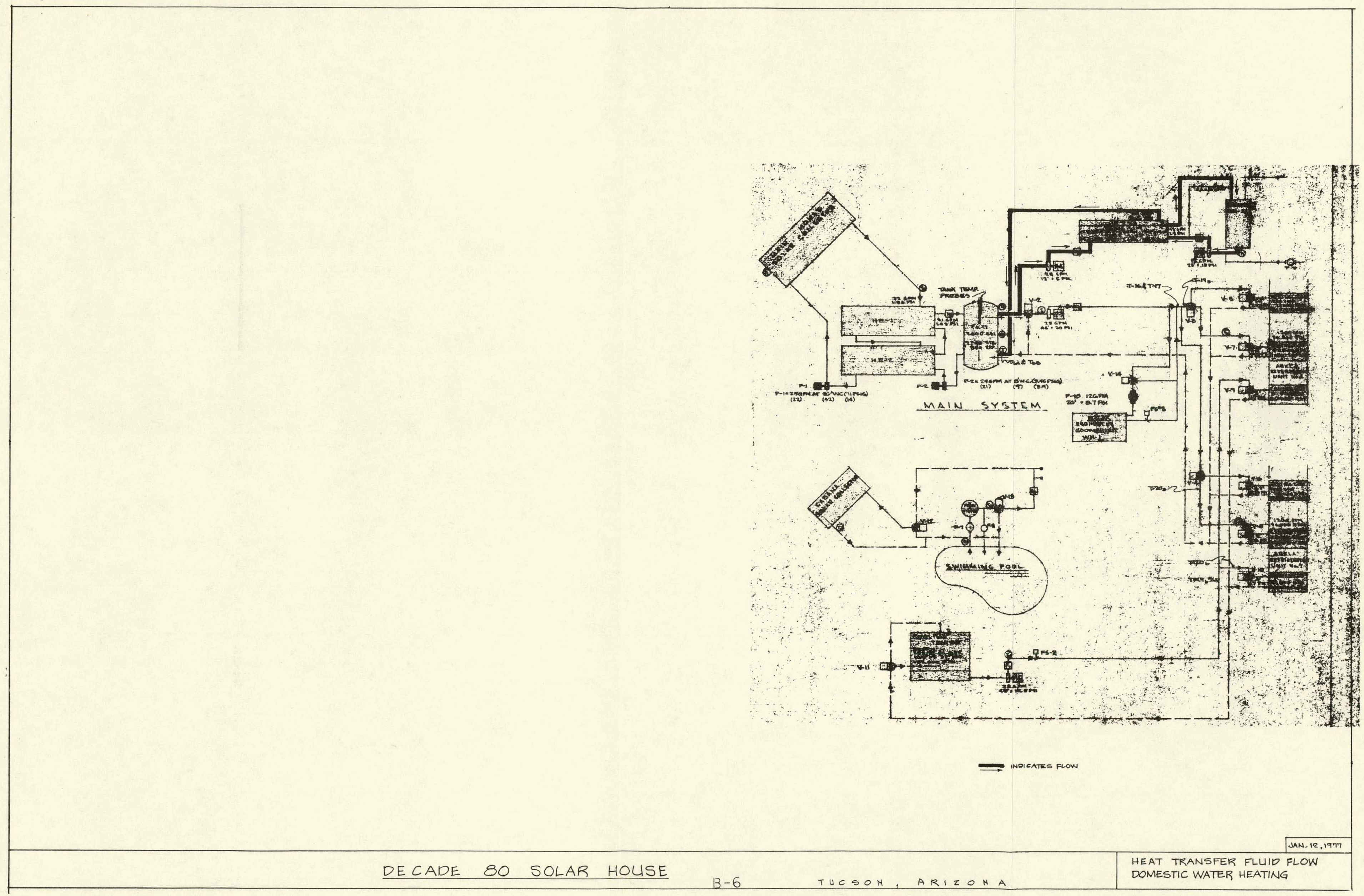




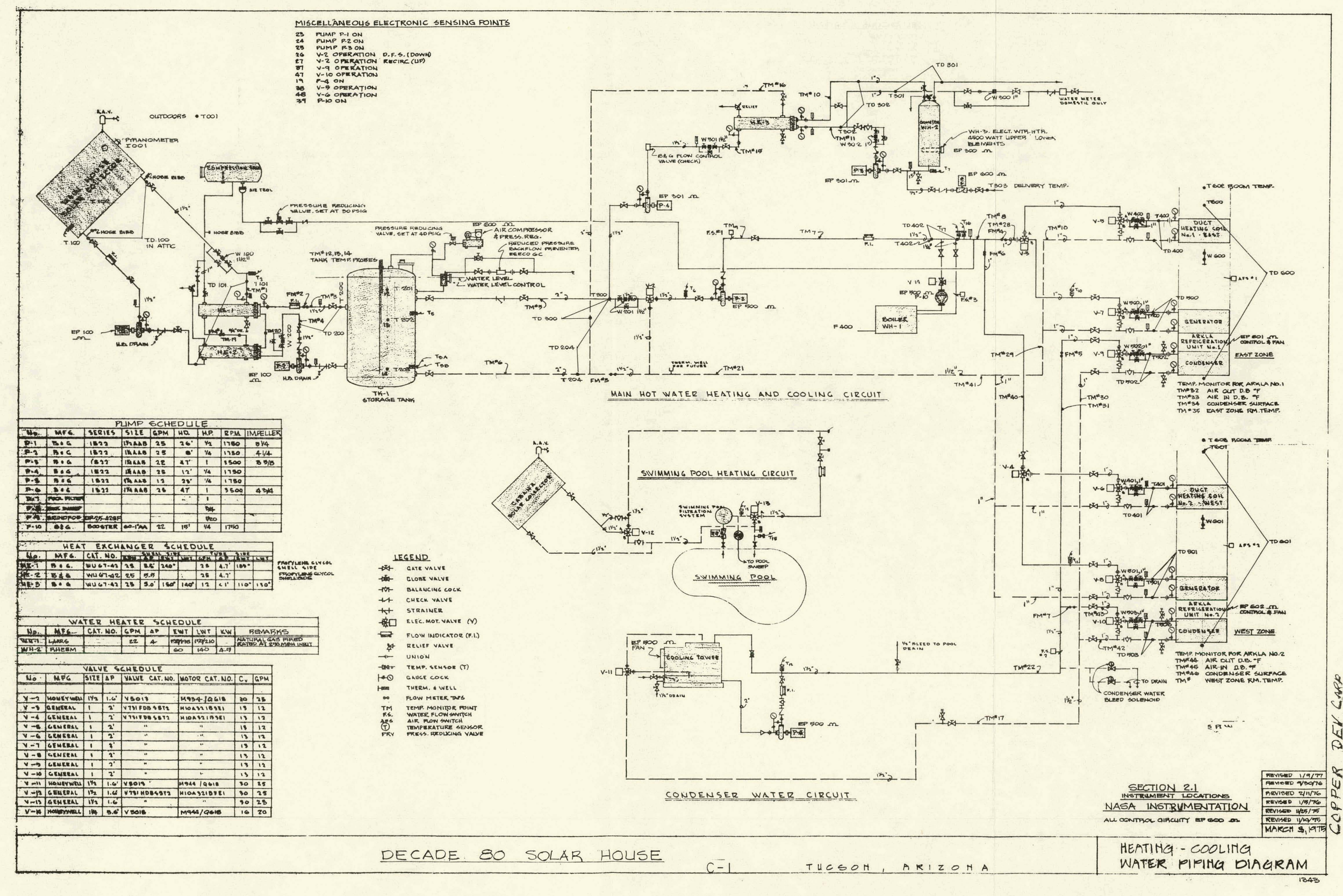

